\title{
ARTICLE
}

\section{Hybrid Entity Mismatches and the International Trend of Matching Tax Outcomes: A Critical Approach}

\author{
Leopoldo Parada*
}

\begin{abstract}
The international tax debate as regards hybrid entities has certainly changed after the OECD BEPS Project. Since then, the trend has been focused exclusively on matching transactions involving hybrids and reverse hybrid entities and double non-taxation, bowever without questioning whether these two elements are necessarily interconnected or whether they should serve each other in the design of domestic anti-hybrid provisions. This is particularly evident as regards the notion of 'bybrid (entity) mismatch arrangements' the design of which is based on the assumption that income should be taxed somewhere - no matter where - and as regards the complex set of domestic solutions proposed ('linking rules') the true efficacy of which is nevertheless still unknown.

In this vein, this article adopts a critical approach both as regards the diagnosis of the problems and as regards the solutions proposed. As to the diagnosis, the author argues that the artificial attempt to match transactions involving hybrid entities and double non-taxation not only disregards the fundamental issue as regards hybrid entity mismatches (i.e. the disparate tax characterization of the same entity by two different states), but also carries with it the risk of creating presumptions of abusive practices in all those cases in which a bybrid entity structure is simply not taxed at all. As to the remedies, the author argues against the complexity, excessive reliance on foreign laws and potential economic double taxation issues that the implementation of linking rules might cause from a tax policy perspective. From a practical perspective, the author questions the proper interaction between linking rules and other anti-base erosion provisions, such as interest limitations and CFC rules. This article ultimately concludes that a re-orientation in the international debate regarding bybrids and reverse bybrid entities is crucial in order to open the door for more fundamental - and perhaps also more coordinated - solutions.
\end{abstract}

\section{INTRODUCTION}

The international tax debate as regards hybrids entities has certainly changed after the OECD BEPS Project. ${ }^{1}$ Since then, the trend has been exclusively focused on matching transactions involving hybrids and reverse hybrid entities and double non-taxation, however without questioning whether these two elements are necessarily interconnected or whether they should serve each other in the design of domestic anti-hybrid provisions. ${ }^{2}$ This is especially evident in the notion of 'hybrid (entity) mismatch arrangements', the design of which is based on the assumption that income should be taxed somewhere - no matter where ${ }^{3}$ - and in the complex set of domestic

\section{Notes}

LL.M. (Florida, USA), Ph.D. (Valencia, Spain) is a postdoctoral research fellow at the IBFD in Amsterdam and a visiting professor of International Tax Law at the Department of Management of the University of Turin (Italy). Email: 1.parada@ibfd.orgor. leopoldo.parada@unito.it.

OECD, Addressing Base Erosion and Profit Shifting (OECD Publishing 2013). See also OECD, Action Plan on Base Erosion and Profit Shifting (OECD Publishing 2013). For an early analysis of the OECD BEPS Report, see Y. Brauner, BEPS: An Interim Evaluation, 6 World Tax J. 1 (2014).

This article deals exclusively with the domestic effects of hybrid entity mismatches. Therefore, a consideration of issues related to hybrids and reverse hybrid entities and tax treaties is beyond the scope of this article. Accordingly, this article will refer exclusively to cases involving the use of hybrid entity structures resulting in a deduction/non-inclusion (double nontaxation). Therefore, other cases considered in the OECD BEPS Action 2, such as hybrid entity transactions resulting in double deduction or dual resident mismatches are excluded. The reason for this is that while the former cases are not strictly related to double non-taxation, the latter cases do not refer exclusively to hybrid entities.

Some authors refer to this single taxation idea as a principle of international tax law ('single tax principle'), which would rest - together with the benefit principle - in the bilateral tax treaty network and in domestic tax laws of the major trading nations, forming also part of customary international law. R. Avi-Yonah, International Tax as International Law: An Analysis of the International Tax Regime 8-13 (Cambridge University Press 2007). See also R. Avi-Yonah, International Taxation of Electronic Commerce, 52 (3) Tax L. Rev. 507 (1997). Supporting this idea, see e.g. H. Ault, The Importance of International Cooperation in Forging Tax Policy, 26(4) Brook. J. Int'l L. 1693 (2001); H. Ault, Some Reflections on the OECD and the Sources of International Tax Principles, 70(12) Tax Notes Int'l 1195 (2013); Y. Brauner, An International Tax Regime in Crystallization, 56 Tax L. Rev. 259 (2003); Y. Brauner, Integration in an Integrated World, 2 N. Y. U. J. L. \& Bus. 51 (2005); L. Dell'Anese, Tax Arbitrage and the Changing Structure of International Tax Law (Egea 2006). More recently, see R. Avi-Yonah, Who Invented the Single Tax Principle?. An Essay on the History of U.S. Treaty Policy, 59(2) N.Y.L. Sch. L. Rev. 309 (2015); R. Avi-Yonah, The International Tax Regime: A Centennial Reconsideration, University of Michigan Public Law Research Paper 462 (25 June 2015$)$. In contrast, see e.g. H. D. Rosenbloom, The David R. Tillinghast Lecture: International Tax Arbitrage and the 'International Tax System', 53 Tax L. Rev. 137 (2000); H. D. Rosenbloom, Cross-Border Arbitrage: The Good, The Bad and the Ugly, 85(3) Taxes: The Tax Magazine 155 (2007); J. Roin, Competition and Evasion: Another Perspective on International Tax Competition, 89(3) Geo. L.J. 543 (2001); M. Kane, Strategy and Cooperation in National Responses to International Tax Arbitrage, 53 Emory L.J. 89 (2004); M. Graetz, Taxing International Income: Inadequate Principles, Outdated Concepts and Unsatisfactory Policies, 26(4) Brook. J. Int'l L. 1357 (2001). Shaviro has also recently criticized the simplistic construction of the single tax principle, especially in reference to tax treaties and double taxation relief. As provided by Shaviro: 'Tax treaties generally require that the signatories eliminate "double taxation" [... The treaties also commonly seek to address "fiscal evasion" funderstood by some commentators as the avoidance of "double non-taxation"] [...] Put the two concern together and you arguably have a "single tax principle" [...]'. D. Shaviro, The Two Faces of the Single Tax Principle, N.Y.U. Law \& Economics Working Papers, Paper 419 (2015), at 1. 
solutions proposed to counteract them - 'linking rules' - the true efficacy of which is nevertheless still unknown. ${ }^{4}$

In this vein, this article adopts a critical approach both as regards the diagnosis of the problems and as regards the solutions proposed. As to the diagnosis, the author argues that the artificial attempt to match transactions involving hybrids entities and double non-taxation not only disregards the fundamental issue as regards hybrid entity mismatches (i.e. the disparate tax characterization of the same entity by two or more states), but also carries with it the risk of creating presumptions of abusive practices in all those cases in which a hybrid entity structure is simply not taxed at all. As to the remedies, the author argues against the complexity, excessive reliance on foreign laws and potential economic double taxation issues that the implementation of linking rules might cause from a tax policy perspective. From a practical perspective, the author questions the proper interaction between linking rules and others anti-base erosion provisions, such as interest limitations and CFC rules. The article ultimately concludes that a re-orientation in the international debate regarding hybrids and reverse hybrid entities is crucial in order to open the door for more fundamental - and perhaps also more coordinated - solutions.

Section 2 analyses the notion of hybrid entity mismatch arrangements and criticizes its limited construction. It also argues that the trend of linking disparities resulting from the different tax characterizations of the same entity by two different jurisdictions and the double non-taxation outcome represents a consequentialist approach that should be avoided, especially because it creates presumptions of abusive practices in all those cases in which a transaction involving hybrid entities results in a deduction/non-inclusion outcome, ultimately restricting the ability of the taxpayers to efficiently manage their businesses. Section 3 turns the analysis to the OECD linking rules, which are proposed as a remedy to hybrid entity mismatches. This section argues against the complex design and implementation of these rules, which generate significant concerns from both a tax policy perspective and a practical perspective. From a tax policy perspective, this section stresses the complexity, excessive reliance on foreign laws and potential economic double taxation issues that the implementation of linking rules might cause. From a practical perspective, this section argues that linking rules still raise questions as regards coordination with others anti-base erosion provisions, particularly as regards interest limitation rules and CFC rules. Section 5 provides some final remarks, emphasizing the need for more fundamental and coordinated solutions as regards hybrid entity mismatches.

\section{HyBRID ENTITY MISMATCHES: A PRAGMATIC DIAGNOSTIC OF THE PROBLEM}

In 2015 the OECD issued the final report on Action 2 referring to 'hybrid mismatch arrangements' in general as arrangements that 'exploit differences in the tax treatment of an entity or instrument under the laws of two or more jurisdictions to achieve double non-taxation, including long term deferral'. 5 In this regard, therefore, and attending exclusively to hybrids and reverse hybrid entities, it is possible to conclude that a hybrid entity mismatch arrangement' will occur when an entity organized in a determined country is regarded as either a tax transparent or tax opaque in that country, while in the other country it is characterized exactly in the opposite manner, and the result of this disparity creates a mismatch in the payments made under that arrangement, i.e. a deduction/non-inclusion or double deduction outcome. ${ }^{6}$ Therefore, at least three elements will trigger the recognition of a hybrid entity mismatch: (1) the 'hybrid entity element' or the disparity in the characterization of the same entity by two or more countries involved in the transactions, (2) the existence of a 'payment' between the two parties involved in the hybrid entity structure and (3) a deduction/noninclusion outcome (i.e. double non-taxation).

This section briefly analyses these three elements, arguing against the consequentialist approach assumed in the whole design of the concept of hybrid entity mismatch arrangements. In particular, the author stresses the idea that the concept of hybrid entity mismatch arrangements

\section{Notes}

Nonetheless, the OECD already referred to the concept of 'hybrid mismatch arrangements' in its 2012 report, which is the anteroom of the proposals included in the BEPS Action 2 Final Report. OECD, Neutralising the Effects of Hybrid Mismatch Arrangements - Action 2: 2015 Final Report, OECD/G20 Base Erosion and Profit Shifting Project (OECD Publishing 5 Oct. 2015). See also OECD, Hybrid Mismatch Arrangements: Tax Policy and Compliance Issues (OECD Publishing 5 Mar. 2012).

OECD, Action 2 Final Report, supra n. 4, at 11. A similar definition was included in the Action 2 deliverable (2014), which provided that a hybrid mismatch arrangement is 'an arrangement that exploits a difference in the tax treatment of an entity or instrument under the laws of two or more tax jurisdictions to produce a mismatch in tax outcomes where that mismatch has the effect of lowering the aggregate tax burden of the parties to the arrangement'. Before the 2014 Report, the OECD also issued a public discussion draft. OECD, Discussion Draft, BEPS Astion 2. Neutralise the Effects of Hobrid Mismatch Arrangements (Recommendations for Domestic Lawis) (OECD Publishing 19 Mar. 2014). The comments received were later on summarized in a separate document. OECD, Comments Received on Public Discussion Drafts, BEPS Action 2: Neutralise the Effects of Hybrid Mismatch Arrangements (OECD Publishing 7 May 2014).

O. Popa, Hybrid Entity Payments: Extinct Species After the BEPS Action Plan?, 59(9) Eur. Tax'n 408 (2014). See also P. Carman, BEPS Action 2: Hybrid Mismatch Arrangements, 17 (3) Derivs. \& Fin. Instrums. (2015), at s. 3.1; L. Mechtler, Hybrid Mismatches im Ertragsteuerrecht, 19 (Lexis Nexis 2017). Particularly as regards double non-taxation and the use of hybrids, see L. Parada, Double Non-Taxation and the Use of Hybrid Entities: An Alternative Approach in the New Era of BEPS (Kluwer Law International 2018). For an analysis of double non-taxation within the European Union, see also C. Marchgraber, Double Non-Taxation and EU Law (Kluwer Law International, Eucotax Series 2017). 
creates a presumption of abusive practices in all those cases in which a transaction involving hybrid or reverse hybrid entities results in a deduction/non-inclusion outcome, thus restricting the ability of taxpayers to efficiently manage their businesses.

\section{I The 'Hybrid Entity Element': Hybrid and Reverse Hybrid Entities}

Generally speaking, a bybrid entity is an entity that is seen as a taxable or opaque entity in the country of its organization, while in the country of the investors the same entity is regarded as fiscally or tax transparent. ${ }^{7}$ In other words, the entity under analysis is subject to taxation at the level of the entity in its country of organization, while in the country of the shareholders is considered tax transparent (i.e. non-taxable at the level of the entity but rather at the level of the shareholders). ${ }^{8}$ A reverse bybrid entity, on the other hand, supposes exactly the opposite situation, namely an entity considered as a tax transparent entity in its country of organization, while as a taxable entity in the other country where the shareholders are resident. ${ }^{9}$ Therefore, hybrid entities and reverse hybrids are the result of the different tax characterization of the same entity in two jurisdictions - which is indeed a sovereign decision of states. ${ }^{10}$ In other words, the hybrid entity element simply recognizes an obvious reality of international taxation: domestic rules among different jurisdictions are not necessarily coordinated, let alone harmonized, and this is not the exception for rules characterizing foreign entities for tax purposes. ${ }^{11}$

Although the relevance of the hybrid entity element is evident (i.e. in absence of a disparity in the tax characterization of the same entity, no hybrid mismatch arrangement would exist), sometimes its relevancy is reduced. This is because sometimes countries do not provide the alternative for tax transparency within their domestic law or because they do not have specific rules to characterize a foreign entity as tax transparent. ${ }^{12} \mathrm{~A}$ similar conclusion might be made in the case of countries that provide for

\section{Notes}

The OECD Glossary of Tax Terms states that a hybrid entity is '... an entity that is characterized differently in two or more jurisdictions, for example, an entity that is treated as a partnership in one jurisdiction and as a corporation in another'. OECD, Glossary of Tax Terms, http://www.oecd.org/ctp/glossaryoftaxterms.htm (accessed 30 June 2018). Likewise, the IBFD International Tax Glossary states that a hybrid entity is '... generally, an entity that is characterized as transparent for tax purposes (e.g. as a partnership) in one jurisdiction and non-transparent (e.g. as a corporation) in another jurisdiction'. An entity that is treated, from the point of view of a particular jurisdiction, as transparent in that jurisdiction and as non-transparent in the other jurisdiction is sometimes referred to as 'regular hybrid'. IBFD International Tax Glossary (7th ed. June 2015). Hybrid entities can be very useful for tax planning purposes, particularly when the some parties of a joint venture vehicle want it to be treated as tax transparent and the others as seek for a corporate treatment. For an analysis of this specific situation, see R. Ward, Some Problems with Hybrid Entities, 2(2) Corp. Tax Rev. 147 (1999).

8 This explanation coincides with the traditional tax treatment of partnerships. However, this article will not refer exclusively to those entities, and will also include, e.g. references to single ownership entities not taxed at the level of the entity, but rather at the level of the single owner such as the case of a limited liability company (LLC) in the United States. Regarding the tax treatment of US partnerships, see e.g. L. Cunningham \& N. Cunningham, The Logic of Subchapter K: A Conceptual Guide to the Taxation of Partnerships, 4th ed. (West 2011). See also P. McDaniel, M. McMahon, Jr. \& D. Simmons, Federal Income Taxation of Partnerships and S Corporations, 4th ed. (Foundation Press 2006). Although other countries follow a tax transparency treatment for partnerships similar to that applied in the United States (e.g. Australia, Germany and Sweden), there are also examples of countries that nevertheless apply taxation at the level of the entity, such as Belgium and Hungary. J. Barenfeld, Taxation of Cross-Border Partnerships, Double Tax Relief in Hybrid and Reserve Hybrid Situations, in IBFD Doctoral Series vol. 9, s. 2.3.2.2 (IBFD 2005).

9 The Glossary of the IBFD refers to a 'reverse hybrid entity' as follows: '[A]n entity is a reverse hybrid when it is treated from the point of view of a particular jurisdiction as non-transparent and as transparent in the other. A hybrid entity is, therefore, also always a reverse hybrid, the difference depending on whether the classification is being made from the point of view of the jurisdiction treating the entity as transparent (hybrid) or non-transparent (reverse hybrid)'. IBFD, International Tax Glossary, 7 th ed. (June 2015). A particularly sensitive area of analysis regarding reverse hybrids refers to 'trust-based mismatches'. Indeed, trusts can be used to give rise to reverse hybrids in respect of income. Although this specific analysis is excluded from this article, for an in-depth - and critical - analysis of OECD BEPS Action 2 as regards trusts, see M. Brabazon, BEPS Action 2: Trusts as Hybrid Entities, 2 Brit. Tax Rev. 211 (2018).

10 The majority of countries opt for a comparative approach or resemblance test to characterize foreign entities for tax purposes. That is, a foreign entity is considered as a taxable or tax transparent entity depending of the level of comparability or equivalence to domestic taxable entities. E.g. Germany applies a resemblance test (Rechtstypenvergleich) in a two-level manner. First, the foreign entity is evaluated in the abstract according to the applicable foreign corporate law. Second, and once this abstract evaluation has been completed, a specific legal comparison between the foreign and domestic corporate characterization is made. For a further explanation of the German resemblance test, see C. Kahlenberg, Classification of Foreign Entities for German Tax Purposes, 54(4) Eur. Tax'n (2014). See also U. Henkel, Subjektfähigkeit grenzüberschreitender Kapitalgesellschaften, 7 Recht der internationalen Wirtschaft 565 (1991). The Netherlands also applies a resemblance test to characterize foreign entities for tax purposes that relies on the company law features of an entity determined according to its foreign incorporation statutes or contracts. The test is currently reflected in a decree published by the Dutch Minister of Finance dated 11 Dec. 2009. NL: Decree of the State Secretary of Finance, CPP2009/519M of 11 Dec. 2009. Although the decree has no legal binding power, taxpayers may rely on it based on the principle of 'legitimate expectations' (vertrouwensbeginsel) as this is the official interpretation made by the State Secretary of Finance. See M. De Graaf \& J. Gooijer, the Netherlands, in Qualification of Taxable Entities and Tax Treaty Protection IFA Cabiers $2014-$ Volume $99 B 563$ (M. Lang \& C. Staringer eds, IFA 2014). Before the implementation of the US check-the-box regulations in 1996 (taxpayer elective system), the United States also characterized foreign entities for tax purposes using a resemblance test known as the 'Kintner test'. This test considered the concurrence of four corporate features, including limited liability, continuity of life, centralized management and free transferability of interests. P. E. Hobbs, Entity Classification: The One Hundred-Year Debate, 44(2/3) Cath. U. L. Rev. 437 (1995). See also M. Gianni, International Tax Planning After Check-the-Box, 2 J. Passthrough Entities 39 (1999). The Kintner test and the company features considered thereunder owes its name to the case of US v. Kintner. US. CA 9th Cir. 14 Oct. 1954, United States $v$. Kintner. 216 F2d 418 (9th Cir. 1954). For the current US check-the-box regulation, see US: Treas. Reg. s. 301.7701-3. For a detailed analysis of the different rules used by countries around the world to characterize foreign entities for tax purposed - including a detailed explanation of the US check-the-box system, see Parada, supra n. 6, at 118-157.

11 Parada, supra n. 6, at 118

12 This is the case of some developing countries. E.g. Brazil and Colombia do not provide for domestic tax transparent partnerships. In Uruguay, a partnership the partner of which is a company also resident in Uruguay, is not regarded as tax transparent either. Likewise, e.g. Brazil, Colombia and South Africa do not have rules that allow the treatment of a foreign subsidiary as a tax transparent entity. For a full analysis with respect to the problem of hybrid mismatch arrangement and developing countries, particularly with respect to Brazil, Colombia, South Africa and Uruguay, see B. Ku囚niacki, A. Turina et al., Preventing Tax Arbitrage via Hybrid Mismatches: BEPS Action 2 and Developing Countries, WU International Taxation Research Paper Series No. 2017-03 (31 Mar. 2017) 
coordination in the tax characterization of a foreign entity either by statute, ${ }^{13}$ administrative practice ${ }^{14}$ or transposition of supranational law. ${ }^{15}$

Another significant issue with respect to the hybrid entity element concerns cases of 'partial tax transparency', such as the case of trusts and limited liability partnerships (LLPs). ${ }^{16}$ Although this issue is not directly considered in the BEPS Action 2-Final Report (domestic recommendations), it is indeed analysed within the tax treaty recommendations part of the same Report, which states:

In the case of an entity or arrangement which is treated as partly fiscally transparent under the domestic law of one of the Contracting States, only part of the income of the entity or arrangement might be taxed at the level of the persons who have an interest in that entity or arrangement $[\ldots]$ whilst the rest would remain taxable at the level of the entity or arrangement. ${ }^{17}$

Therefore, one could conclude that in cases of partial transparency, only the part of the entity treated as tax transparent by one state and taxable by the other state could give rise to the 'hybrid entity element'. In other words, if the state of an LLP treats an entity as fiscally transparent only with respect to the general partners, while the other country considers the LLP as taxable in full, only the part of the income or payments associated to the general partners could give rise to the hybrid element that subsequently might give rise to a hybrid entity mismatch arrangement.

\subsection{The Existence of a 'Payment' and the Tax Relevancy of the Hybrid Transaction}

The second element of the notion of a hybrid entity mismatch arrangement refers to the existence of a 'payment' between the parties involved in the hybrid entity structure. ${ }^{18}$ In this regard, the BEPS Action 2 Final Report states that a 'payment' is:

any payment of money (which includes money's worth) made under the financing instrument and includes a distribution, credit or accrual. It includes an amount that is capable of being paid and includes any future or contingent obligation to make a payment. The definition of payment includes notional amounts that accrue in respect of a future payment obligation even when the amount accrued does not correspond to any increase in the payment obligation during that period. ${ }^{19}$

Accordingly, a payment is considered as such when the relevant payment obligation is incurred under the laws of the payer jurisdiction or the payment is derived under the laws of the recipient jurisdiction. ${ }^{20}$ The Action 2 Final Report, however, expressly excludes a unilateral deduction

\section{Notes}

13 E.g. Denmark applies some specific rules - by statute - which provide for coordination in the tax characterization of its own domestic entities in accordance with the tax characterization given by the foreign country to cases of both hybrids and reverse hybrid entities. The Danish rules were a targeted reaction to the characterization of entities derived specifically from the use of the US check-the-box rules. A. Møllin Ottosen \& M. Nørremark, New Anti-Avoidance Rules in Denmark Targets Reverse Hybrids and Convertible Bonds, 68(11) Bull. Int'l Tax'n 513 (2008). See also J. Bundgaard, Coordination Rules as a Weapon in the War against Cross-Border Tax Arbitrage: The Case of Hybrid Entities and Hybrid Financial Instruments 67(4/5) Bull. Int'l Tax'n (2013); J. Wittendorff, Denmark's Hovmand Clarifies Pending Transparent Entities Legislation 33(9) Tax Notes Int'l (2004); Dell'Anese, supra n. 3, at 254. For an analysis of these rules, see also Parada, supra n. 6, at 162-172.

14 An example of coordination by administrative practice is the practice of the DGT (Spanish tax administration) to follow the characterization in the foreign country, regardless that by statute the Spanish domestic law provides for a resemblance test. D. Jiménez-Valladolid de L'Hotellerie-Fallois \& F. Vega Borrego, Spain, in Corporate Income Tax Subjects vol. 12, 460-464 (D. Gutmann ed. EATLP International Tax Series 2016). See also A. Mosquera Mouriño, Régimen de atribución de rentas: especial referencia a las actividades económicas, 4 Carta Tributaria 3-16 (2012). This practice has been ratified by several binding rulings issued by the Spanish tax administration, including e.g. ES: DGT, Consulta Vinculante V1398-16 of 5 Apr. 2016; ES: DGT, Consulta Vinculante V3319-16 of 17 July 2016; ES: DGT, Consulta Vinculante V3836-15 of 2 Dec. 2015; ES: DGT, Consulta Vinculante V1631-14 of 25 June 2014; ES: DGT, Consulta Vinculante V0012-11 of 11 Jan. 2011; ES: DGT, Consulta General 0024-07 of 1 July 2007; DGT, Consulta General 0196-05 of 1 June 2005, among others. For an analysis of the Spanish administrative practice, see Parada, supra n. 6, at 158-162.

15 An attempt at coordination at source can be found in the original text of the EU Anti-Tax Avoidance Directive (EU ATAD I). European Commission, Proposal for a Council Directive laying down rules against tax avoidance practices that directly affect the functioning of the internal market COM (2016) 26 final (28 Jan. 2016), Art. 10(1). However, the final text arrived at later on proposing the OECD linking rules. EU Anti-Tax Avoidance Directive (ATAD I): Council Directive (EU) $2016 / 1164$ of 12 July 2016 laying down rules against tax avoidance practices that directly affect the functioning of the internal market, OJ L193/1 (19 July 2016), Art. 9. For an early analysis, see A. Navarro, L. Parada \& P. Schwarz, The Proposal for an EU Anti-avoidance Directive: Some Preliminary Thoughts 25(3) EC Tax Rev, 117 (2016). The ATAD II (on hybrid mismatch arrangements with third countries outside the EU) proposed a rule resembling the Danish anti-hybrid rule already mentioned as regards reverse hybrid entities. See EU AntiTax Avoidance Directive II (EU ATAD II): Council Directive (EU) $2017 / 952$ of 29 May 2017 amending Directive (EU) 2016/1164 as regards hybrid mismatches with third countries OJ L 144/1 (7 June 2017), Art. 9a. For a further analysis of Art. 9a ATAD II, see G. Fibbe \& A. J. A. Stevens, Hybrid Mismatches under the ATAD I and ATAD II, 26 (3) EC Tax Rev. 153 (2017). For a recent analysis regarding the coordination experiences in Denmark, Spain and the EU in relation with tax treaties, see L. Parada, Hybrid Entities and Conflicts of Allocation of Income Within Tax Treaties: Is the New Article 1(2) OECD Model [Article 3(1) MLI] the Best Solution Available?, 3 Brit. Tax Rev. (2018).

16 E.g. in the Netherlands an 'open commanditaire venootschap' is always considered tax transparent for the general partners, while it is taxed at the level of the entity with respect to the limited partners. Similarly, the 'société en commandite simple' in France provides for tax transparency with respect to the general partners, while the limited partners are not taxed under the regime of transparency. In this regard, Baker distinguishes at least four levels of transparency: (1) complete transparency, where the entity has no existence, e.g. a contractual joint venture, or where the entity is completely disregarded for tax purposes; (2) transparency with reporting obligations, where the entity has still the obligation to report income or gains, but the tax liability remains on the participants; (3) optional transparency, where the entity or participants may elect for transparency; and (4) partial transparency, where part of the income of the entity is taxed in the hands of the entity and part in the hand of the participants. P. Baker, The Application of the Convention to Partnerships, Trusts and Other, Non-Corporate Entities, 2(1) GITC Rev. 22-23 (2002).

17 OECD, Action 2 Final Report, supra n. 4, at 141 (proposed para. 26.11 of the Commentary on Art. 1(2) of the OECD Model).

18 As provided in the BEPS Action 2 Final Report: 'The extent of a mismatch is determined by comparing the tax treatment of the payment under the laws of each jurisdiction where the mismatch arises'. OECD, Action 2 Final Report, supra n. 4, at 17.

19 OECD, Action 2 Final Report, supra n. 4, at 130 (emphasis in original). A payment should also include a part of a payment where the context requires.

20 OECD, Action 2 Final Report, supra n. 4, at 130. 
for invested equity that does not require a payment from the taxpayer, such as the case of 'deemed interest deductions for equity ${ }^{21}$ and differences in the value with respect to a payment, such as the case of gain or losses from foreign currency fluctuation. ${ }^{22}$

However, the determination of what is a 'deemed interest deduction' or whether there is a 'payment' can become complicated, especially considering the differences among the regimes on notional interest deduction around the world. An example of this is the Belgian notional interest deduction regime, which provides the possibility for any company subject to corporate income tax in Belgium to deduct from its taxable base a so-called 'notional interest deduction' (déduction pour capital à risquê). ${ }^{23}$ The notional interest deduction is calculated by multiplying a fictitious interest rate by the relevant equity, which is determined by adjusting certain deductions and based on the nonconsolidated annual accounts of the previous accounting year. ${ }^{24}$ Likewise, the interest rate is determined considering the interest rate of medium long-term linear government bonds (so-called OLO bonds, obligations lineaireslineaire obligatie). ${ }^{25}$ Nonetheless, it is arguable that the Belgian notional interest deduction is indeed considered as a 'deemed interest deduction' when it is calculated as a function of net equity invested, first; and second, it does not refer at all to effective loan transactions entered into with related or unrelated parties. ${ }^{26}$
Another example can be found in the treatment of Brazilian interest payments on net equity (juros sobre 0 capital próprio). ${ }^{27}$ Indeed, in the mid-1990s Brazil introduced an option for Brazilian companies to deduct from their taxable base the remuneration of net equity as 'notional interest'. ${ }^{28}$ Generally speaking, the deduction is calculated on a daily basis, multiplying the relevant net equity by a legal rate of interest (taxa de juros de longo plazo) which is published quarterly by the Brazilian Central Bank and the basis of which is the inflation rate, increased by a risk premium. ${ }^{29}$ Accordingly, two other significant features of the Brazilian juros should also be considered. First, the existence of current profits or accumulated earnings of certain amounts is a pre-condition for the company to make the distribution and to consider the deductibility of those payments. ${ }^{30}$ Second, the juros must be paid or credited to resident and non-resident shareholders, ${ }^{31}$ and once paid or credited, the notional interest is subject to a $15 \%$ withholding tax,${ }^{32}$ which is indeed a final tax in the case of individuals. ${ }^{33}$

Therefore, in principle, under the definition of payments in the BEPS Action 2 Final Report, one could conclude that these amounts - juros - are indeed payments, as they are capable of being paid. ${ }^{34}$ However, the requirement that current or accumulated earnings exist in order to make a distribution and in order to consider those amounts deductible, first; and second, the fact that

\section{Notes}

21 As explained in the BEPS Action 2 Final Report, these payments would be 'economically closer to a tax exemption or similar taxpayer specific concessions and do not produce a mismatch in tax outcomes in the sense contemplated by Action 2'. OECD, Action 2 Final Report, supra n. 4, at 18.

22 'The hybrid mismatch rules are not generally intended to pick-up mismatches that are attributable to differences in the value ascribed to a payment. E.g. gain and losses from foreign currency fluctuations on a loan can be said to give rise to mismatches in tax outcomes but these mismatches are attributable to differences in the measurement of the value of payments (rather than its character) and can generally be ignored for the purposes of the hybrid mismatch rules'. OECD, Action 2 Final Report, supra n. 4, at 18.

23 W. Heyvaert \& D. Deschrijver, Belgium Stimulates Equity Financing, 33(10) Intertax 458 (2005). See also M. Gérard, Belgium Moves to Dual Allowance for Corporate Equity, 46(4) Eur. Tax'n (2006). Other European countries have also introduced similar regimes. See e.g. the cases of Latvia (2008), Portugal (2008), Lichtenstein (2011) and Italy (2011). For further references in the case of Latvia, see Z. Kronbergs, Latvia-2014 Corporate Tax Changes, 54(11) Eur. Tax'n (2014); in the case of Portugal, see G. J. Oliveira Everaert, Portugal - Corporate Taxation, s. 1. (IBFD), para. 1.7.1.7 (accessed 30 July 2018); in the case of Lichtenstein, see B. Büchel, Liechtenstein - Corporate Taxation, s. 1. (IBFD), para. 1.3.3 (accessed 30 July 2018). For Italy, see e.g. F. Leone \& E. Zanotti, Notional Interest Deduction Regime Introduced, 52(8) Eur. Tax'n (2012). For a comparative analysis of these regimes, see also F. Massimi \& C. Petroni, Real-World ACE Reforms and the Italian Experience. Towards a General Trend?, 40(11) Intertax 632 (2012).

24 Heyvaert \& Deschrijver, supra n. 23, at 459.

25 This is an ongoing programme under which the Belgian Treasury issues notes of different maturity. For purposes of the Belgian notional interest deduction in tax years 2008 and thereafter, the fictitious interest will be the average interest rate of the 10-years Belgian treasury notes for the second year preceding the tax year. Heyvaert \& Deschrijver, supra n. 23, at 459

26 A. Bax \& S. Claes, The New Belgium-US Income Tax Treaty: An Analysis, 47(7) Eur. Tax'n 353 (2007).

27 BR: Law 9, 249/95 of 26 Dec. 1995, Art. 9

28 J. Malherbe \& G. Vettori, Deducting Interest on Equity Capital: Brazilian and Belgian Tax Rules Compared, 1 Eur. Tax Stud. 28 (2010). See also C. Bastianello, Juros sobre o capital próprio: Natureza jurídica e tratamento conferido pela lei interna e pelos tratados para evitar dupla tributasáa internacional firmados pela República Federativa do Brasil, in Direito Tributário Internacional Aplicado, vol. III, 721-762 (Quartier Latin 2005). For an analysis of conflicts of qualification within tax treaties due to the use Brazilian juros, see F. Martínez Laguna, Institutional Hybrid Financial Instruments and Double Non-Taxation under Domestic Rules and Tax Treaty Law: The Example of Spain, 44(6/7) Intertax 447 (2016).

29 Martínez Laguna, supra n. 28, at 450.

30 Martínez Laguna, supra n. 28, at 451. Originally, the payments were dependent on current benefits or retained earnings in the amount of two times the juros paid, but the limit of $50 \%$ of the accumulated profits from previous years was no longer available after the adoption of IFRS in Brazil. Thus, profits from previous years must have a specific destination and such accounts do not exist anymore. A. Akie Utumi, Brazil, in The Debt Equity Conundrum, vol. 97b, 140 (P. Brown ed., IFA Cahiers 2012).

31 Massini \& Petroni, supra n. 23, at 636.

32 It is important to consider that the distribution of dividends out of profits to residents and non-residents is not subject to withholding tax in Brazil. In addition, since 2015 dividends are determined according to IFRS. E. Salomão Neto \& J. Prada Levy, Corporations and Partnerships in Brazil 118-120, s. III (Kluwer Law International 2011).

33 Massini \& Petroni, supra n. 23, at 637.

34 Amounts capable of being paid include 'notional amounts that accrue in respect of a future payment obligation even when the amount accrued does not correspond to any increase in the payment obligation during that period'. OECD, Action 2 Final Report, supra n. 4, at 130. 
the company is not liable for any payments related to the equity participation with the shareholders, ${ }^{35}$ reinforces the idea that if a payment is made - or accrued, it does not correspond to a future payment obligation, as there is indeed no obligation to pay off interest, but an option to distribute benefits to shareholders. ${ }^{36}$ In other words, the Brazilian juros would be closer to a unilateral deduction for invested equity that does not require a payment by the taxpayer. ${ }^{37}$

As noted, therefore, the 'payment' element is neither easy to determine nor free from criticism. ${ }^{38}$ However, this should not prevent the recognition of its significance in order to determine the existence of a hybrid entity mismatch arrangement. Indeed, it is the 'payment' that will make the hybrid entity structure ultimately relevant for tax purposes. ${ }^{39}$ In other words, in the absence of such a payment, the disparity in the tax characterization of entities ('hybrid element') should not be per se considered an international concern. This also ensures that the countermeasures created to deal with hybrid entity mismatches (OECD linking rules) do not apply automatically, but only to the extent that a relevant tax payment has been made.

\subsection{The Double Non-Taxation Outcome: A Consequentialist Approach}

The existence of a transaction involving hybrid and reverse hybrid entities and a payment derived from that transaction is still not enough to confirm that a hybrid entity mismatch arrangement has arisen. Indeed, according to the BEPS Action 2 Final Report, it is required that this payment generates a deduction in the payer state ${ }^{40}$ and a non-corresponding inclusion of ordinary income in the payee state. ${ }^{41}$ In other words, the double non-taxation outcome will be the core element in order to confirm the existence of a hybrid entity mismatch arrangement, demonstrating the consequentialist approach adopted by the OECD on this matter. This consequentialist approach can be illustrated using both hybrid and reverse hybrid entities structures. The author hereafter refers to these situations separately. ${ }^{42}$

\section{Notes}

35 Martinez Laguna, supra n. 28, at 451.

36 Ibid.

37 In this regard, the Brazilian regime resembles the Belgian notional interest deduction, which calculates the interest on a function of net equity invested and does not refer at all to effective loan transactions. Bax \& Claes, supra n. 26. See also OECD, Action 2 Final Report, supra n. 4, at 18. Although beyond the scope of this article, it is evident also that potential conflicts of qualification at the level of tax treaties might arise. This was indeed an issue already subject to judicial scrutiny in Spain. ES: National Court (Audiencia Nacional), SAN 27.2.2014, r. 4. For a more extensive analysis of this specific matter, see Martínez Laguna, supra n. 28. See also M. Cencerrado Milán \& M. Soler Roch, Limit Base Erosion via Interest Deduction and Others, 43(1) Intertax 58, 64-65 (2015); M. Lorán \& E. Villa, Hybrid Mismatches and the BEPS Project: A Spanish Perspective on Brazilian Juros, 19(2) Derivs. \& Fin. Instrums. (2017)

38 In this regard, see G. Cooper, Some Thoughts on the OECD's Recommendations on Hybrid Mismatches, 69(6/7) Bull. Int'l Tax'n 342 (2015). Cooper argues, e.g. that a duplication of (Foreign Tax Credit) FTC can occur without the need of a 'payment' between the two claimants. Cooper's argument appears to be recognized by the OECD, when it states that 'payments that do not involve the creation of economic rights between the parties' are not regarded as payments. OECD, Action 2 Final Report, supra n. 4 , at 123.

39 The reference to a payment that makes a transaction 'tax relevant' mirrors a US tax rule that applies in the case where an eligible entity elects to treat a foreign entity in a manner different from that provided by the US default classification rules. For this purpose, US tax law provides that 'a foreign entity's classification would be relevant if US income was paid to the entity [...]' (emphasis added). US: Treas. Reg. s. 301.7701-3(d)(1)(i). Generally speaking, the US check-the-box system provides that an 'eligible (foreign) entity' (i.e. an entity not listed as a per se corporation in Treas. Reg. s. 301.7701-2(b)(8)) may elect to be classified either as an association, which is taxable as a corporation in the United States, or as a partnership, which is taxable only at the level of the partners. US: Treas. Reg. s. 301.7701-3(a). The election may be made at any time and it must accomplish with the formal requirements established by law ('entity classification election') jointly with its federal tax or information return of the taxable year in which the election is made. If the entity is not required to file a return for that year, i. e. attaching a copy of Form 8832 to the federal tax or information return of any direct or indirect owner of the entity for the taxable year in which the election is made. US: Treas. Reg. s. $301.7701-3(c)(1)($ ii). However, in absence of an election, the tax status of a foreign business is settled by default rules based on limited liability and the number of owners of the foreign entity. US: Treas. Reg. s. 301.7701-3c)(1)(iv). For a further analysis of the US check-the-box system and the tax planning opportunities generated by its use, see Parada, supra n. 6, at 129-157. In reference to the US check-the-box rules, see also D. M. Benson et al., 'Hybrid' Entities: Practical Application Under the Check-the-Box Regime, 26(8) Tax Mgmt. Int'l J. 363 (1997); B. N. Davis, U.S. Tax Treatment of 'Reverse Hybrid' Foreign Entities, 24(12) Tax Mgmt. Int'l J. 593-596 (1995); Gianni, supra n. 10; H. Mogenson et al., Hybrid Entities: Practical Application under the Check-the-Box Regime, 23(1) Int'l Tax J. 1 (1997)

40 The BEPS Action 2 Final Report states that: 'Deduction (including deductible payment), in respect to a payment, means that, after a proper determination of the character and treatment under the laws of the payer jurisdiction, the payment is taken into account as a deduction or equivalent tax relief under the laws of that jurisdiction in calculating the taxpayer's net income'. OECD, Action 2 Final Report, supra n. 4, at 121. Therefore, a payment will be taken as a deduction when under the laws of the payer jurisdiction it is part of the calculation of the taxpayer's net income.

41 The BEPS Action 2 Final Report considers that a payment will be treated as 'included in ordinary income' in the country of the recipient 'to the extent that, after a proper determination of the character and treatment of the payment under the laws of the relevant jurisdiction, the payment has been incorporated as ordinary income into a calculation of the payee's income under the law of that jurisdiction'. OECD, Action 2 Final Report, supra n. 4, at 122. Accordingly, ordinary income is understood as 'means income that is subject to tax at the taxpayer's full marginal rate and does not benefit from any exemption, exclusion, credit or other tax relief applicable to particular categories of payments (such as indirect credits for underlying tax on income of the taxpayer)'. OECD, Action 2 Final Report, supra n. 4, at 123. Finally, the OECD provides that 'income is considered subject to tax at the taxpayer's full marginal rate notwithstanding that the tax on the inclusion is reduced by a creditor other tax relief granted by the payee jurisdiction for WHT or other taxes imposed by the payer jurisdiction on the payment itself. OECD, Action 2 Final Report, supra n. 4 , at 122.

42 All of the examples below assume that no withholding tax is ever applied at source. Accordingly, no tax treaty issues are considered in order to simplify the explanations of this section. For a recent tax treaty analysis of the implications of hybrids and reverse hybrid entities in light of the new Art. 1(2) of the OECD Model Convention (replicated in Art. $3(1)$ of the MLI), see A. Nikolakakis et al., Some Reflections on the Proposed Revisions to the OECD Model and Commentaries, and on the Multilateral Instrument, with respect to Fiscally Transparent Entities, 3 Brit. Tax Rev. 295 (2017), republished in two parts as A. Nikolakakis et al., Some Reflections on the Proposed Revisions to the OECD Model and Commentaries, and on the Multilateral Instrument, with Respect to Fiscally Transparent Entities-Part 1, 71(9) Bull. Int'l Tax'n (2017); \& A. Nikolakakis et al., Some Reflections on the Proposed Revisions to the OECD Model and Commentaries, and on the Multilateral Instrument, with Respect to Fiscally Transparent Entities-Part 2, 71(10) Bull. Int'l Tax'n (2017). One of the proposals suggested an approach to integrate the determination of the beneficial ownership and the application of Art. 1(2) OECD Model. This proposal is nevertheless criticized in Parada, supra n. 6, at 255-264. In a different and more recent article, Parada also stresses an alternative solution to deal with hybrid and reverse hybrid entities in tax treaties which would be through the use of a domestic rule that coordinates the characterization of entities for tax purposes. According to the author, this solution would not only eliminate any potential hybrid entity mismatch before the application of any treaty, but would also indirectly provide more consistent tax treaty outcomes without needing to replace or modify the current wording of Art. 1(2) of the OECD Model. For further analysis, see Parada, Hybrid Entities and Conflicts of Allocation of Income Within Tax Treaties, supra n. 15. 


\subsection{Illustrations Using Hybrid Entity Structures}

Assume that ACo, a taxable entity incorporated in State $A$, grants a loan to BSub, an entity organized in State $B$ and wholly owned by ACo. BSub pays back interest of 100 connected to that loan. State $B$ does not apply a withholding tax at source. While State $A$ considers BSub as tax transparent, State $B$ considers the same entity as a taxable or opaque entity.

Figure 1: Illustration Using a Hybrid Entity Structure

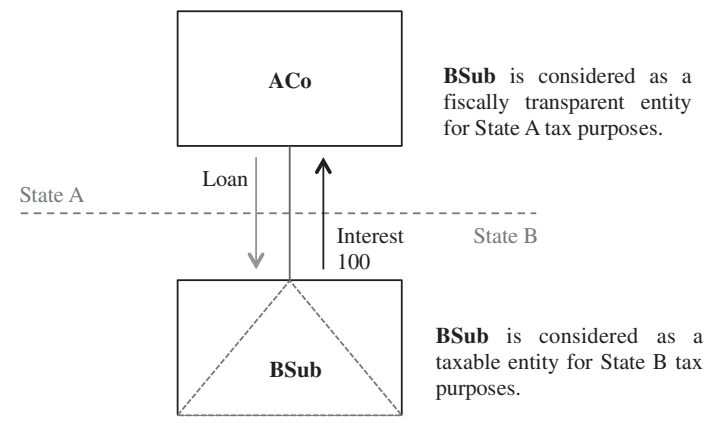

In this scenario, the 100 of interest paid by BSub will be considered a deduction for purposes of the calculation of BSub's taxable income in State $B$, as BSub is indeed considered to be a taxable or opaque entity in that state. Accordingly, the interest paid will not be included as ordinary income by ACo, because under the tax laws of State $A$, BSub is considered as a tax transparent entity. In other words, for State $A$ 's tax purposes, the loan and the interest are completely disregarded and the final result is a deduction/non-inclusion of income. As noted, therefore, the double non-taxation outcome plays the final role in determining that a hybrid entity mismatch arrangement exists and that it should be counteracted.

The analysis above is nevertheless incomplete. Indeed, the excessive concern demonstrated by the OECD regarding double non-taxation (consequentialist approach) might completely disappear when one considers other factors in the analysis of hybrid entity structures, such as group taxation and multiyear taxation. ${ }^{43}$ Taking the same example in Figure 1: Illustration Using a Hybrid Entity Structure, assume that BSub also has a subsidiary in State $B$
(BSub1), which together with BSub form a tax group. Also, assume two different scenarios. The first scenario is that BSub1 in Year 1 has income of 100 and BSub pays interest of 100 , but has no income. In Year 2, however, BSub has income of 100, but pays no interest. BSub1 has no income. Thus, in Year 1 and Year 2 together, the combined income of the group is $200 .^{44}$

Figure 2: Group Taxation-First Scenario

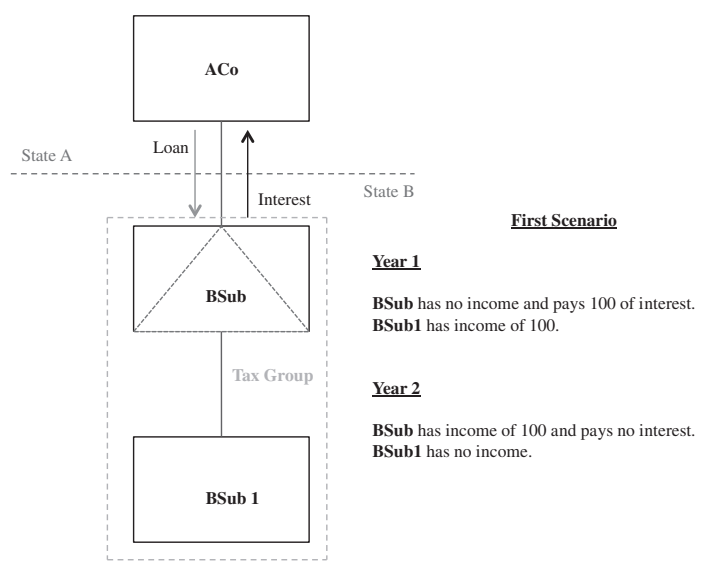

If one disregards the second year, the result of the first scenario is that the income of the group is offset against the interest deduction. Accordingly, the interest payments are not included as income in State $A$, as the loan transaction is completely disregarded. In other words, if one isolates Year 1, a deduction/noninclusion outcome (double non-taxation) arises. However, if one considers Year 1 and Year 2 together, and assumes that no foreign tax credit is granted by State $A$ in Year 2 , the result in Year 2 is that 100 will be included in the tax base of both State $A$ and State $B$, which reflects the combined income of the group. Therefore, if the true concern regarding this transaction is that income is not taxed at all in Year 1, this can easily be resolved considering the double inclusion of income in Year 2, without granting a foreign tax credit in State $A .{ }^{45}$ Moreover, when group taxation and multi-year taxation come into play, it is easier to realize that the double non-taxation outcome is more apparent than real. Indeed, the real outcome when considering the two years together is a one-year

\section{Notes}

43 This idea was originally stressed by Lüdicke, in J. Lüdicke, 'Tax Arbitrage' with Hybrid Entities: Challenges and Responses, 68(6/7) Bull. Int'l Tax'n 309, 317 (2014).

44 These assumptions are taken from the analysis that Lüdicke makes with respect to hybrid entities and deduction/non-inclusion outcomes in order to demonstrate that the assumption that a deduction/non-inclusion occurs is indeed relative. Lüdicke, supra n. 43.

45 Lüdicke, supra n. 43 , at 314. 
deferral, but not properly a permanent double nontaxation outcome. ${ }^{46}$

In the second scenario, BSub has no income or expenses in Year 2 and BSub1 pays dividends of 100 to BSub. Thus, the economic burden of the group in both years taken together is 100 .

Figure 3: Group Taxation-Second Scenario

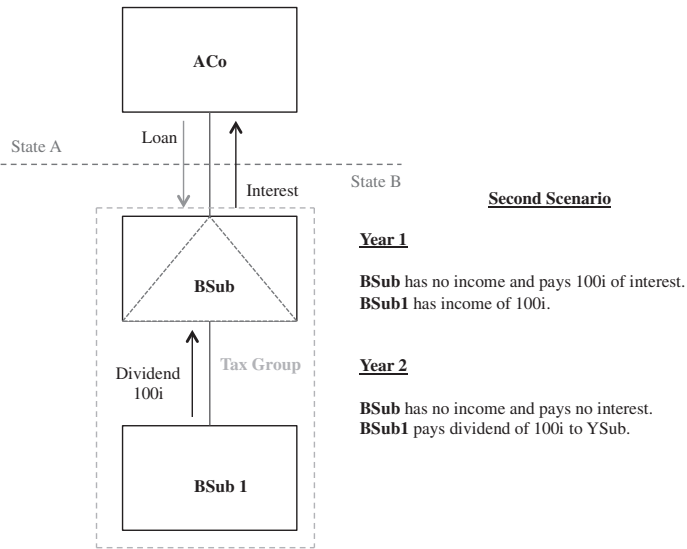

Indeed, in the second scenario, the dividends paid from BSub1 to BSub will be taxable in State $A$, but not in State $B$, as the underlying income was already attributed to and taxed in State $A$ in Year 1 (i.e. the 100 of income that BSub1 had in Year 1). There will be no foreign tax credit in State $A$ in Year 1, as income and expenses were offset due to the group taxation in State $B$. Thus, the overall result considering Year 1 and Year 2 is the taxation of the combined income of the group (100), although having one year of deferral. Once again, double non-taxation is rather apparent when one considers the two years together and the effects of group taxation. In other words, a one-year deferral is put on equal footing as a permanent double non-taxation outcome. ${ }^{47}$

\subsubsection{Illustrations Using Reverse Hybrid Entity Structures}

Now, assume a triangular structure involving a reverse hybrid entity. In the example below, BSub is a reverse hybrid entity, such that under the tax law of State $B$, BSub is considered as a transparent entity, while State $A$ and State $C$ consider BSub as a taxable or opaque entity. Accordingly, assume that BSub receives interest from CSbub1, a sub-subsidiary that is established in State $C$.

Figure 4: Illustration using a reverse bybrid entity structure

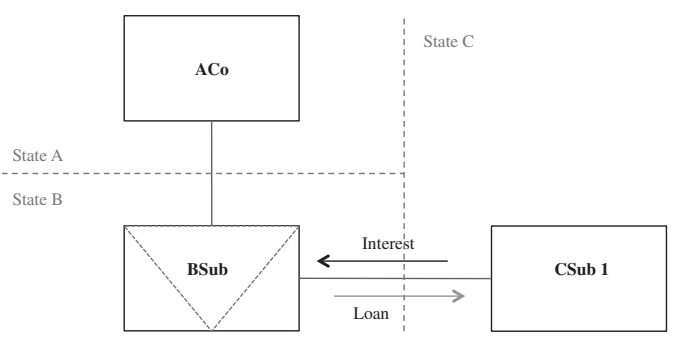

As noted in this simple example, the interest paid to BSub will be deductible in State $C$, but not recognized as ordinary income either in State $B$, where BSub is regarded as a tax transparent entity, or in State $A$, where the entity is regarded as tax opaque. In other words, the existence of a hybrid entity mismatch arrangement in this case relies exclusively on the deduction/non-inclusion outcome or non-taxation all together, even though this outcome might not necessarily be a definitive outcome at all. ${ }^{48}$

However, the concern as regards the disparity in the tax characterization of BSub disappears if the tax outcome is different than double non-taxation, demonstrating once again the consequentialist approach adopted by the OECD as regards hybrid entity mismatches. For example assuming the same facts as above with the only difference that BSub pays interest to ACo, the final tax outcome would be 'non-deduction/inclusion' rather than a deduction/non-inclusion. Indeed, due to the tax transparency treatment of BSub in State $B$, interest payments will not be deductible in State $B$, but they will be included as ordinary income - and most probably taxed - in State A. Nevertheless, such an outcome is excluded from the concern of the BEPS Action 2 Final Report. ${ }^{49}$

\section{Notes}

46 Ibid.

47 Double non-taxation is indeed an ambiguous concept the proper understanding of which is generally underestimated. For an analysis of the different attempts to explain this concept, see $\mathrm{e}$ g. Parada, supra n. 6, at 13-22. As concluded by this author: '.... the boundaries of the notion of DNT should remain within its nature of a simple outcome, absent of subjective interpretations, not being thus regarded per se as a cause of concern'. Parada, supra n. 6, at 51. In the same line of reasoning, Marchgraber correctly explains: ' ... not all situations where something remains untaxed are necessarily problematic ... But even with regard to those scenarios of alleged double non-taxation that are considered to be problematic from a tax policy perspective, referring to the phenomenon of double non-taxation is not in itself sufficient to prove that there is a legal problem ... Hence, the term double non-taxation seems to be legally inexistent'. Marchgraber, supra n. 6, at 13 .

48 E.g. if State $A$ provides for strict CFC rules, it is at least to be expected that the non-distributed profits at the level of BSub will be taxable in State $A$ as CFC income. See s. 3.3.1, infra.

49 OECD, Action 2 Final Report, supra n. 4, at 59-60. 
Figure 5: Reverse Hybrid Entity (Non-Deduction/Inclusion)

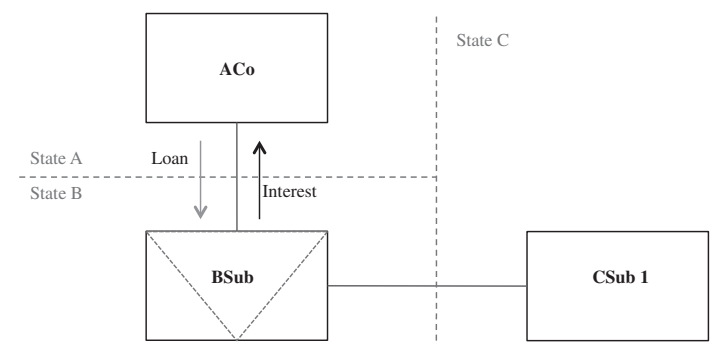

Similarly, if one assumes now that BSub pays interest to CSub1, the tax outcome will depend of the tax treatment of BSub in State C. If, on the one hand, BSub is considered as a taxable entity (as it is in State $A$ as well), the final tax outcome will be non-deduction/ inclusion, which is outside the scope of the BEPS Action 2 Final Report. ${ }^{50}$ If, on the other hand, State $C$ treats BSub as a tax transparent entity (as it is originally considered in State B), the tax outcome of the transaction will be a 'non-deduction/non-inclusion of income'.

Figure 6: Reverse Hybrid Entity (Non-Deduction/NonInclusion)

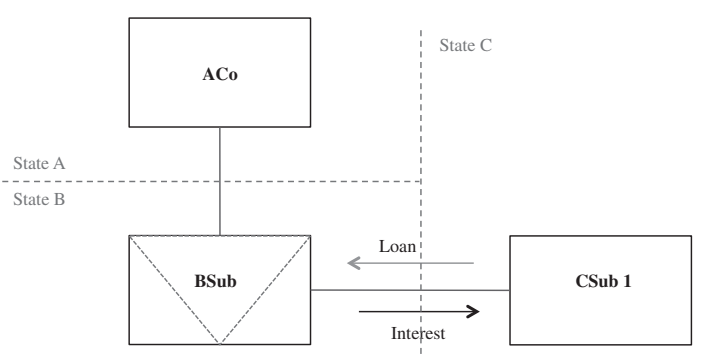
If State C treats BSub as a taxable entity, the outcome will be a 'non-deduction/inclusion'.
On the contrary, if State C treats BSub as a tax transparent entity, the outcome will be a 'non-deduction/non-inclusion', i.e. double non-taxation-

Indeed, due to the tax transparency treatment of BSub in State $B$, no deduction will be allowed. Accordingly, State $C$ will disregard the whole loan transaction due to the tax transparency of BSub. Curiously, however, this non-taxation outcome remains outside the scope of BEPS Action 2. ${ }^{51}$ This confirms once again the pragmatic OECD approach, because if double non-taxation were to be the evil, there would be no reason to exclude this latter outcome either. ${ }^{52}$

\section{OECD LINKING RULES: A PRAGMATIC SOLUTION FOR A PRAGMATIC DIAGNOSTIC}

The pragmatic approach of matching tax outcomes in the case of transactions involving hybrid and reverse hybrid entity structures has also given rise to pragmatic solutions. Indeed, BEPS Action 2 recommends a twolevel domestic solution to deal with hybrid entity mismatch arrangements, namely a primary response and a defensive rule, which together are known as 'linking rules. ${ }^{53}$

This section argues against the complex design of these rules, which generate significant concerns from both a tax policy perspective and a practical perspective. From a tax policy perspective, this section stresses the complexity of linking rules, their excessive reliance on foreign laws and the potential economic double taxation issues that their implementation might cause. From a practical perspective, linking rules still raise questions as regards the coordination with other anti-base erosion provisions, particularly as regards interest limitation rules and CFC rules. All of these issues are analysed below.

\section{I Primary Response and Defensive Rule in a Nutshell}

As noted, the OECD linking rules provide for a twolevel domestic reaction to deal with cases of transactions involving hybrid and reverse hybrid entities the

\section{Notes}

so Ibid.

51 Ibid.

52 The only reason would be to consider that a deduction is indeed a presumption of base erosion, which appears to be the OECD approach.

53 In spite of the fact that OECD linking rules are recommendations, there are countries that have already started introducing or at least discussing their introduction into domestic laws, especially regarding hybrid mismatch arrangement resulting from the use of hybrid financial instruments. E.g. s. 12(1) No. 10 of the Austrian Corporate Income Tax Law provides for a denial of the interest paid to a foreign corporation if the receiving corporation belongs to the same group and the payment is exempted at the level of the foreign receiving corporation or the income is subject to an effective tax rate of less than $10 \%$. M. Jann, J. Schuch \& G. Toifl, Austria - Corporate Taxation s. 1 (IBFD), s. 1.4 .10 https://online ibfd org $/$ kbase/\#topic $=$ doc\&url $=\% 252 \mathrm{Fhighlight} \% 252 \mathrm{Fcollections} \% 252 \mathrm{Fcta} \%$ 252Fhtml\%252Fcta_at_s_001.html\&q=austria +austrias\&WT.z_nav=outline\&hash=cta_at_s_1.4.10. (accessed 25 Sept. 2018). Similarly, Art. 15(j) of the Spanish Corporate Income Tax Law introduced a rule applicable to hybrid instruments, which provides that expenses of a transaction between related parties will not be considered as deductible if due to a conflict of qualification they do not generate income or generate exempted income or income subject to a nominal tax rate below $10 \%$ at the level of the recipient. ES: Art. 15(j) of the Corporate Income Tax Law [Ley del Impuesto sobre Sociedades], as introduced by Royal Law Decree [Real Decreto Legislativo] 4/2004 of 5 Mar. 2014. See also Á. de la Cueva González-Cotera \& C. Morlán Burgasé, Spain - Corporate Taxation s. 1 (IBFD) https://online.ibfd.org/kbase/\#topic=doc\&url=/highlight/collections/cta/html/cta_es_s_001.html\&q=Spain\&WT.z_nav=Search (accessed 25 Sept. 2018). In Germany, the introduction of a similar provision disallowing an interest to the extent the recipient does not characterize the income received as interest was discusses, although it has not yet entered into force. D. Gutmann et al., The Impact of the ATAD on Domestic Systems: A Comparative Survey, 57(1) Eur. Tax'n 17 (2017). 
outcome of which is a deduction/non-inclusion. ${ }^{54}$ The first level-reaction, i.e. the primary response, consists in denying a deduction for the payments if they are not included as ordinary income in the recipient country. ${ }^{55}$ In other words, the limitation on the deductibility of payments made by a hybrid entity are contingent to the fact that these payments are not considered ordinary income in the recipient state due to the different tax characterization of the same entity. A payment must therefore originally be allowed as a deduction in order to apply the primary response. ${ }^{56} \mathrm{~A}$ second level-reaction (i.e. a defensive rule) consists in recognizing the payment as ordinary income in the country of the recipient, being a mirror image of the primary recommendation above-mentioned. ${ }^{57}$ The defensive rule therefore applies only to the extent that the payer state does not disallow the deduction of the payment and thus that the non-taxation outcome of this payment remains as a risk. ${ }^{58}$

\section{I.I Linking Rules and Hybrid Entity Structures}

Consider an illustration of this using the facts of Figure 1: Illustration Using a Hybrid Entity Structure. In this case a primary response in State $B$ will imply that BSub will be prevented from deducting the 100 of interest when calculating its taxable income to the extent that the same 100 of interest is not recognized as ordinary income by ACo in State $A$. If, for any reason, State $B$ decides not to deny the deduction of interest, State $A$ should react in this case by recognizing the transaction originally disregarded by the tax transparent treatment of BSub and, therefore, recognizing the interest received as ordinary income in State $A .{ }^{59}$
Figure 7: Primary Response and Defensive Rule (Hybrid Entity)

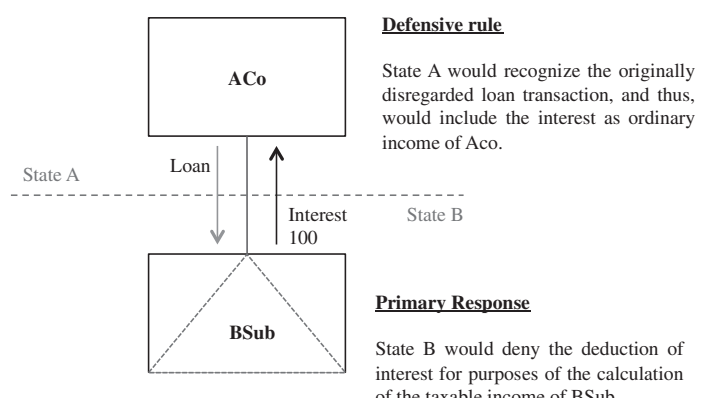

of the taxable income of BSub.

Although the effects of the primary response are rather clear, as it works like any other rule limiting the amount of interest deduction (i.e. increasing the taxable base of the payer (BSub) by the amount of disallowed interest payments), the analysis of the effects of the defensive rule deserves special attention.

As noted in the figure above, one might be tempted to conclude a priori that the defensive rule provides a kind of implicit recognition of the tax characterization of the entity (BSub) - in State $B$, as State $A$ must recognize the interest payment as income, i.e. as if BSub were a taxable or opaque entity rather than a tax transparent one. ${ }^{60}$ Thus, the defensive rule would establish a sort of de facto coordination rule. Nevertheless, this statement is far from true. A defensive rule provides that income should be recognized as ordinary income in the state of the payee entity, which is not the same as providing that the tax characterization of the entity at source should prevail.

Indeed, if such a rule were to be established in order to coordinate the tax characterization in both countries,

\section{Notes}

54 However, these solutions apply with some limitations, i.e. not every single hybrid entity mismatch that gives rise to a deduction/non-inclusion outcome may trigger the application of the rules. Indeed, only hybrid entity mismatches that are within the context of either a 'control group' or a so-called 'structured arrangement' are included within the scope of application. OECD, Action 2 Final Report, supra n. 4, at 49 \& 55. For an analysis of both the concept of 'control groups' and 'structured arrangements' in light of the complexity of linking rules, see s. 3.2.1, infra. Finally, and although this article does not deal with the OECD tax treaty proposals as regards hybrid entity mismatches (i.e. Art. 1(2) of the OECD Model), a proper analysis of these issues can be found in: Nikolakakis et al., supra n. 42. See also Parada, supra n. 6, at 187-275; and, more recently, Parada, Hybrid Entities and Conflicts of Allocation of Income Within Tax Treaties, supra n. 15.

55 As stated by the OECD: 'Both payments made under hybrid financial instruments and payments made by and to hybrid entities can give rise to D/NI outcomes. In respect of such hybrid mismatch arrangements this report recommends that the response should be to deny the deduction in the payer jurisdiction'. OECD, Action 2 Final Report, supra n. 4 , at 17 .

56 As provided by the OECD: ‘[...] the disregarded hybrid payments rule should only operate to the extent that the payer is entitled to a deduction for a payment under local law'. OECD, Action 2 Final Report, supra n. 4, at 51. The interaction of the primary response and interest limitation rules is analysed at s. 3.3.2, infra.

57 OECD, Action 2 Final Report, supra n. 4, at 52

58 The contingent application of the defensive rule is clearly stated by the OECD when it provides: 'If the payer jurisdiction does not neutralize the mismatch then the payee jurisdiction will require such payment to be included in ordinary income to the extent the payment gives rise to a D/NI outcome' (emphasis added). OECD, Action 2 Final Report, supra n. 4 , at 49

59 As to the effective taxation in State $A$, this will ultimately depend on the other income and expenses of ACo. Indeed, if ACo has for an $\mathrm{X}$ taxable year more expenses than income - including ordinary interest - no effective taxation will affect the interest anyway.

60 Accordingly, and with respect to hybrid financial instruments, one could argue that the defensive rule acts also in a similar way as a 'switch-over clause' that permits switching off the application of the exemption method. In this regard, see e.g. A. Rust, BEPS Action 2: 2014 Deliverable-Neutralizing the Effects of Hybrid Mismatch Arrangements and its Compatibility with the Non-Discrimination Provisions in Tax Treaties and the Treaty on the Functioning of the European Union, 3 Brit. Tax Rev. 308 (2015). 
neither the primary response nor defensive rule would be needed. For example assume that instead of linking rules, a rule giving priority to the tax characterization in the source state is implemented. ${ }^{61}$ In such a case, and using again the example of Figure 1: Illustration Using a Hybrid Entity Structure, State $A$ will follow the tax characterization of BSub in State $B$ where BSub is considered as a taxable entity. Therefore, no mismatch will arise as regards either the tax characterization of BSub or as regards the payment of interest, as the two states will recognize BSub as a taxable entity. In other words, although the payments of interest in this example will still be deductible in State $B$, they will be recognized as ordinary income in State $A$. Thus, neither a primary response nor a defensive rule will be needed.

\subsubsection{Linking Rules and Reverse Hybrid Entity Structures}

As to the cases involving reverse hybrid entities receiving a deductible payment, such as that seen in Figure 5: Illustration Using a Reverse Hybrid Entity Structure, the OECD linking rules apply with some particularities. For example according to the OECD recommendations, only a primary response should be applied at the level of the payer and, in principle, no defensive rule is needed. ${ }^{62}$ This is because the inclusion of income somewhere relies exclusively on the application of CFC rules in the country of the investors or the inclusion of the payment as ordinary income somewhere - no matter where - using any other domestic provision for that purpose. ${ }^{63}$ In the example of Figure 5: Illustration Using a Reverse Hybrid Entity Structure, CSub1 will be denied the deduction of interest payments in State $C$ (primary response) to the extent that interest is not recognized as ordinary income in State $B$ or State $A$. However, if State $A$ applies its CFC rules and therefore taxes the interest payments received by BSub as undistributed profits, no defensive rule would be needed in State $B$.
Figure 8: Defensive Rule and CFC Rules

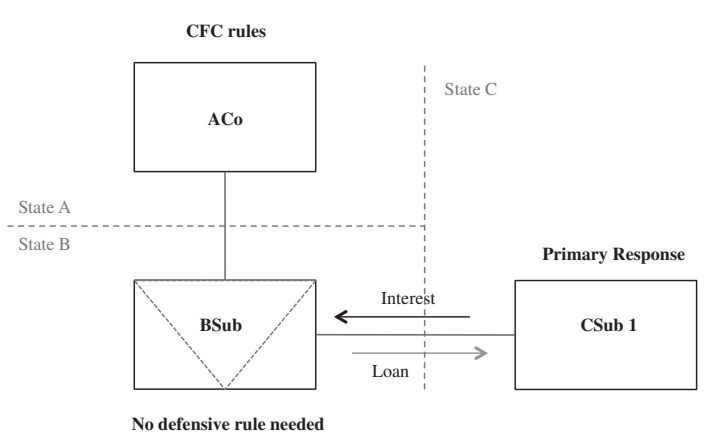

This, however, requires a precise coordination among countries. In other words, the fact that no defensive rule is required if interest is taxed somewhere (e.g. through the use of CFC rules in the country of the investors controlling the reverse hybrid entity), does not prevent State B from indeed applying a defensive rule first - taxing the interest - which subsequently might also be included as ordinary income in the state of the investors (State $A$ ), ultimately generating a double taxation issue. This of course could be avoided if the country of the investors were to grant a tax credit or any other type of double taxation relief. However, and although this appears to be a generalized practice worldwide, it should not be taken for granted. ${ }^{64}$

\subsection{Tax Policy Concerns}

As already stressed in this article, the design and implementation of OECD linking rules dealing with cases of hybrid entity mismatch arrangements raises significant tax policy concerns. These concerns can be summarized as follows: (1) complexity of the rules, (2) excessive dependency on foreign laws and (3) potential economic double taxation issues. These concerns are analysed in below.

\subsection{Complexity}

Despite the pragmatic and simplistic manner in which the OECD linking rules are presented, their application is far

\section{Notes}

61 This idea is not so far from reality. e.g. in Spain a similar rule of coordination is applied by administrative practice, despite the fact that the Spanish tax characterization rules are designed as a resemblance test by statute. See references at, supra n. 14. See also the original proposal on hybrid mismatch arrangements in the EU ATAD, which also opted for a coordination rule. As provided by the original Art. 10(1) of the Proposal: 'Where two Member States give a different legal characterization to the same taxpayer (hybrid entity), including its permanent establishments in one or more Member State, and this leads to either a situation where a deduction of the same payment, expenses or (hybrid entity), including its permanent establishments in one or more Member State, and this leads to either a situation where a deduction of the same payment, expenses or
losses occurs both in the Member State in which the payment has its source, the expenses are incurred or the losses are suffered and in another Member State or a situation where there is a deduction of a payment in the Member State in which the payment has its source without a corresponding inclusion of the same payment in the other Member State, the legal characterization given to the hybrid entity by the Member State in which the payment has its source, the expenses are incurred or the losses are suffered shall be followed by the other Member State' (emphasis added). European Commission, Proposal for a Council Directive laying down rules against tax avoidance practices that directly affect the functioning of the internal market, Art. 10(1), supra n. 15.

62 OECD, Action 2 Final Report, supra n. 4, at 57, para. 149.

63 Ibid.

64 E.g. in the United States s. 960 of the Internal Revenue Code (IRC) provides for a foreign tax credit with respect to the taxes paid at the level of the foreign-controlled entity. If the credit is claimed by corporations, the applicable provision is IRC s. 902 . Likewise, the deemed foreign tax credit under s. 960 is available for taxes paid by subsidiaries through the sixth tier. US: IRC s. 960 and IRC s. 902 
from simple. This refers not only to the technicalities of the rules themselves, but also to the whole design of the concept of a hybrid entity mismatch arrangement in OECD BEPS Action 2, both of which generate serious doubts from a tax policy perspective.

In the first place, one should bear in mind that the concepts of 'deduction', 'inclusion' and '[ordinary] income' should not necessarily coincide in all countries applying a primary response or a defensive rule in order to counteract hybrid entity mismatch arrangements. The OECD states that a deduction 'means that, after a proper determination of the character and treatment under the laws of the payer jurisdiction, the payment is taken into account as a deduction or equivalent tax relief under the laws of that jurisdiction in calculating the taxpayer's net income'. ${ }^{65}$ Therefore, at first glance, one could conclude, for example, that a general limitation on the deductibility of interest affects the proper determination of the character and treatment under the laws of the payer jurisdiction, because indeed it helps to determine the taxpayer's net income. However, the OECD's conclusion on the interaction between interest limitation rules and anti-hybrid rules (linking rules) goes exactly in the opposite direction, giving priority to the application of linking rules. ${ }^{66}$ Accordingly, if one considers the requirement that a payment be included as 'ordinary income' in the payee state, it is possible to conclude a priori that interest payments are included as ordinary income even if losses carried forward from previous years are used to offset this income. A similar conclusion should be reached regarding the role of withholding taxes. Nevertheless, the OECD's position on these two issues is not necessarily consistent.

As to the use of losses, the OECD adopts a proper approach when it states: '[a] payment that is offset against deductible expenditure or losses that have been carriedforward, on this definition, should be treated as having been included in income. ${ }^{67}$ Indeed, deductible expenditures should not affect the fact of recognizing that income is included or not as ordinary income, regardless of whether, due to the offsetting, no taxes are ultimately paid on that income. However, the position regarding withholding taxes is arguable. As stated by the OECD: ' $[t]$ he function of withholding taxes under the laws of the payer jurisdiction is generally not to address mismatches in the tax outcomes and a payment should not be treated as included in ordinary income simply because it has been subject to withholding tax at source'. ${ }^{68}$ However, if one considers that a withholding tax is economically supported at the level of the creditor (or payee), rather than at the level of the payer, this author does not find it consistent that a withholding tax is simply excluded from the concept of inclusion as ordinary income. On the contrary, the application of a withholding tax at source is in line with the main concern regarding hybrid entity mismatch arrangements (single taxation), and reflects also a reality of tax systems around the world. ${ }^{69}$

Still, not considering withholding taxes within the concept of 'inclusion of income' may give rise to unfair results and a true increase in transaction costs. For example if, due to the different characterization of the payer entity, the country of the payee disregards a payment (i.e. it considers the payment as not included as ordinary income) and the payer jurisdiction denies the deduction but applies a withholding tax, the withholding tax will most probably not be credited in the payee jurisdiction because of the non-inclusion of income, and will thereby become a true cost for the whole transaction. ${ }^{70}$

Another perspective to understand the complexity of the OECD linking rules is the fact that their scope is limited to hybrid entity mismatch arrangements concerning a 'control group' or a 'structured arrangement. ${ }^{71}$ At first glance, these limitations in scope can be interpreted so as to avoid an undue complexity of the rules themselves, ${ }^{72}$ implicitly constraining also their application to transactions that might be considered, in principle, as abusive. ${ }^{73}$ However, an in-depth analysis demonstrates exactly the opposite effect, i.e. the broad construction of the concept of 'control group' does not limit the scope of the rules, but rather extends it even

\section{Notes}

65 OECD, Action 2 Final Report, supra n. 4, at 121.

66 This issue is analysed in detail at s. 3.3.2, infra.

67 OECD, Action 2 Final Report, supra n. 4, at 127.

68 Ibid.

69 E.g. in Australia a dividend on a non-equity share paid by an Australian company is likely to be subject to withholding tax at source, which means that the fact the same payment was deductible from the taxable base of the Australian company is, to a certain extent, offset with the application of the withholding tax. Cooper, supra n. 38 , at 348

70 In Australia, e.g. the fact that a company receives interest on a loan that is equity for Australian tax purposes (i.e. not assessable in Australia) changes to the extent a withholding tax is applied at the border, because in such a case the withholding tax will not be creditable in Australia. Cooper, supra n. 38, at 348. That is also the reason why denying a deduction and maintaining a withholding tax at source may transform this withholding tax into a permanent cost. Indeed, as there will be no inclusion of income in the country of the payee, there will be no credit at all. Lüdicke, supra n. 43, at 315, who referring to the explanation of Fig. 4, arrives to the same conclusion.

71 OECD, Action 2 Final Report, supra n. 4, at 49 \& 55.

72 R. de Boer \& O. Marres, BEPS Action 2: Neutralizing the Effects on Hybrid Mismatch Arrangements, 43(1) Intertax 19 (2015).

73 Cooper, supra n. 38, at 342 . 
more, thereby potentially affecting non-abusive hybrid entity transactions. For example the concept of 'control group' includes at least four different scenarios ${ }^{74}$ :

- when there is a consolidation for accounting purposes under IFRS or local GAAP;

- when a person can 'effectively control' the second person through an investment in that person, or there is a third person who has a sufficiently significant investment in both persons so as to give rise to effective control ${ }^{75}$;

- when a person holds, directly or indirectly, ${ }^{76} 50 \%$ or more of the voting rights or value of equity interests ${ }^{77}$ of a second person or a third person holds $50 \%$ or more of the voting rights or value of equity interests in both; and

- when two persons are regarded, for purposes of Article 9 of the OECD Model Tax Convention (OECD Model), as 'associated enterprises'. ${ }^{78}$

It is evident, therefore, that the OECD intention was to include as many situations as possible within the concept of control group in order to prevent manipulation of the rules. ${ }^{79}$ Indeed, if, for example, 'control groups' were to include only the participation of a person in another as a certain percentage of voting rights or equity interest (as happens with other tax rules that require control, such as CFC rules), it would be very easy for taxpayers to circumvent the application of linking rules. Nevertheless, the fear regarding circumvention of the rules should not be used as an argument to increase the level of complexity in the application of linking rules. Moreover, as argued elsewhere, the absence of a bright-line test as regards the control group concept can also be particularly problematic in cases involving trusts. ${ }^{80}$

As to the concept of 'structured arrangements', the story is not much different. The OECD defines structured arrangements as " any arrangement where the hybrid mismatch is priced into the terms of the arrangement or the facts and circumstances (including the terms) of the arrangement indicate that it has been designed to produce a hybrid mismatch'. ${ }^{81}$ Therefore, it is required that the hybrid mismatch be 'priced into the arrangement' or that the 'facts and circumstances' surrounding the arrangement suggest that this was designed to produce a hybrid mismatch. The OECD states, on the one hand, that a hybrid mismatch will be priced into the terms of the arrangement if the mismatch has been factored into the calculation of the return under the arrangement'. ${ }^{2}$ This appears to be an objective test, in that the test focuses only on the terms of the arrangement, without paying attention to other factors, such as the relationship between the parties. The 'facts and circumstances' test, on the other hand, appears to be a more a subjective one. ${ }^{83}$ Indeed, regardless of the fact the OECD provides a non-exhaustive list of facts and circumstances that would suggest that an arrangement should be treated as a structured

\section{Notes}

74 The OECD BEPS Action 2 Final Report states: 'Two persons are in the same control group if: (1) they are consolidated for accounting purposes; (2) the first person has an investment that provides that person with effective control of the second person or there is a third person that holds the investment which provides that person with effective control over both persons; (3) the first person has a $50 \%$ or greater investment in the second person or there is a third person that holds a $50 \%$ or greater investment in both; or (4) they can be regarded as associated enterprises under Art. 9 [OECD Model]'. OECD, Action 2 Final Report, supra n. 4, at 113.

75 The OECD gives the example of a substantial shareholder in a widely held company and that participation gives him the effective control over the appointment of directors. OECD, Action 2 Final Report, supra n. 4, at 116.

76 The understanding of indirect participation (ownership) is rather clear. The OECD illustrates this giving the example of a person $(A)$, who holds $50 \%$ of the shares in BCo, which itself holds also $50 \%$ of CCo. Thus, A would be indirect owner of CCo in a $25 \%$ share of indirect ownership. OECD, Action 2 Final Report, supra n. 4 , at 116 . The concept of indirect ownership coincides with the one used within US law with respect to CFC rules, where the stock held by foreign entities is considered as indirectly owned proportionally by its shareholders or partners. E.g. if $P$ (domestic corporation) owns $80 \%$ of F1 (foreign corporation), and F1 owns $80 \%$ of F2 (foreign corporation), and F2 owns $90 \%$ of $\mathrm{F} 3$ (foreign corporation), $P$ is indirectly owner of $64 \%\left(\begin{array}{lllll}0.80 & 0.80\end{array}\right)$ of $\mathrm{F} 2$ and $57.6 \%\left(\begin{array}{llll}0.80 & 0.80 & 0.90\end{array}\right)$ of F3. B. Bittker \& L. Lokken, Fundamentals of International Taxation: US Taxation of Foreign Income and Foreign Taxpayers 69-10 (Warren, Gorham \& Lamont 2011).

77 The reference to voting rights 'or' equity interest has the clear purpose of preventing circumvention of the rule, e.g. by issuing shares without voting rights. Similar rules are applied, e.g. in the United States with respect to CFC rules. In fact, before 1987, control was measured only by voting power and the alternative of total value was added to avoid manipulation. Bittker and Lokken, supra n. 76, at 69-8; citing US: Staff of Joint Committee on Taxation, 99th Cong., 2nd Sess., General Explanation of the Tax Reform Act of 1986, at 988 .

78 The reason for this inclusion is not entirely clear, as the meaning of 'control' for the purposes of the application of Art. 9 of the OECD Model is left to the domestic laws of the countries. The OECD Model does not give any hints with respect to thresholds or criteria to consider two enterprises as 'associated enterprises'. Nevertheless, the OECD justifies this reference to clarify that linking rules should apply even in the case where a transaction is subject to transfer pricing adjustments. OECD, Action 2 Final Report, supra $\mathrm{n} .4$, at 117.

79 De Boer \& Marres, supra n. 72 , at 19.

80 Although an analysis of trusts is beyond the scope of this article, it is important to highlight the analysis by Brabazon, who provides a critical view as regards the undefined 'effective control' concept in the OECD BEPS Action 2. As stated by Brabazon: 'The Action 2 Report does not stipulate which activities or functions of an entity must be controlled; the question might be significant for a trust under which the control of investments is segregated from entitlements to share in profits or decisions concerning the controlled; the question might be significant for a trust under which the control of investments is segregated from entitlements to share in profits or decisions concerning the
appointment of income or gains. At first blush one might expect the trustees to have effective control of a trust, but the reality can be otherwise. The trustees' deliberative power may be limited in scope or subject to veto. A settlor, appointor, guardian or beneficiary may have the right to remove and replace the trustees. Whether a settlor, etc., has effective control of a trust is treated as a matter of fact'. Brabazon, supra n. 9, at 229.

81 Under the definition above, there are at least three main elements that are required to conclude that a structured arrangement exists, and therefore, to confirm the application of linking rules: (1) the existence of an arrangement; (2) a hybrid mismatch priced into the terms of that arrangement, or facts and circumstances of the arrangement that indicate that the arrangement was designed to produce a hybrid mismatch; and (3) a person being party to this arrangement. OECD, Action 2 Final Report, supra $\mathrm{n}$. 4, at 105. Although the report does not mention it, this author believes that these three elements are interconnected, and therefore, the absence of any of them supposes the failure in passing the test to confirm the existence of a structured arrangement, and subsequently, the application of linking rules.

82 OECD, Action 2 Final Report, supra n. 4, at 105.

83 However, the OECD argues that both tests are indeed objective tests. OECD, Action 2 Final Report, supra n. 4, at 106, para. 319 
arrangement, ${ }^{84}$ all these factors must be considered from the view of an 'objective and well informed observer' who will conclude that the arrangement was designed to produce a hybrid mismatch. ${ }^{85}$

This latter requirement is precisely what introduces the complexity. Assume, for example, a tax planning structure involving the financing of some European subsidiaries through simple loans and the use of US check-the-box rules to avoid CFC rules in the United States (due to passive income received at the level of the subsidiaries). ${ }^{86}$ In addition, assume that the planning is developed by a law firm, which nevertheless writes a report for the taxpayers in a general way, for example as a 'doing business report' rather than a specific tax planning report. In this case, it is evident that the hybrid entity mismatch arrangement will come up after all, because if a parent company in the United States is lending money to a subsidiary in Europe which for US tax purposes is regarded as tax transparent while in Europe is considered as a taxable entity, the interest payments will result in a deduction/no inclusion outcome. ${ }^{87}$ However, if the use of the check-the-box rules were to avoid CFC rules and not to disregard the loan, ${ }^{88}$ it is difficult to affirm that the arrangement was directly designed for the purpose of generating a hybrid entity mismatch. Nevertheless, as the 'facts and circumstances test' also incorporates a term, step or transaction used for the purpose of creating a hybrid mismatch and an arrangement that is 'part of a plan' to create a hybrid mismatch, it could still be possible for an 'objective observer' to consider this tax planning as to be a structured arrangement. ${ }^{89}$ After all, the inconclusive design of the term 'structured arrangement' leaves the door open for further interpretation conflicts, increasing complexity and legal certainty.
Although the complexity introduced by the BEPS Action 2 Final Report as regards hybrid entity mismatches can be illustrated using also other examples, ${ }^{90}$ what it is critical to highlight here is that, from a tax policy perspective, the simplicity of law should be the starting point in the design of measures attempting to regulate transactions involving the interaction of different tax systems. This issue appears - intentionally or not - to have been completely forgotten when it comes to the diagnosis of the problems as regards hybrid entity mismatches and the solution proposed to counteract them.

\subsubsection{Excessive Dependency on Foreign Laws}

Another significant tax policy concern derived from the implementation of the OECD linking rules refers to the excessive dependency on foreign laws that the application of the rules requires. Indeed, once implemented worldwide, it is undeniable that countries' tax laws will become much more contingent on each other. $^{91}$ This contingency, however, should not be confused with the natural degree of dependency that many other international tax rules require for their proper functioning. For example rules on foreign tax credits or CFC rules also require a certain degree of dependency or contingency on foreign laws. ${ }^{92}$ However, this is in any case similar to what appears to be proposed by the OECD linking rules, the level of technicalities of which associated with the knowledge of domestic foreign laws seems to go beyond the simple application of CFC rules or a foreign tax credit. ${ }^{93}$ Indeed, it is difficult to argue that a country could become contingent or structurally dependent on the policies and practices of another country just

\section{Notes}

84 This includes, e.g. arrangements designed, or part of a plan, to create hybrid mismatches; arrangements that incorporate a term, step or transaction used to create hybrid mismatches; marketed arrangements where all the advantages, or some of them, are based on the hybrid mismatch, among others. The full non-exhaustive list includes: '(a) an arrangement that is designed, or is part of a plan, to create a hybrid mismatch; (b) an arrangement that incorporates a term, step or transaction used in order to create a hybrid mismatch; (c) an arrangement that is marketed, in whole or in part, as a tax-advantaged product where some or all the tax advantage derives from the hybrid mismatch; (d) an arrangement that is primarily marketed to taxpayers in a jurisdiction where the hybrid mismatch arises; (e) an arrangement that contains features that alter the terms under the arrangement, including the return, in the event that the hybrid mismatch is no longer available; or (f) an arrangement that would produce a negative return absent the hybrid mismatch'. OECD, Action 2 Final Report, supra n. 4, at 105, Recommendation 10.2.

85 OECD, Action 2 Final Report, supra n. 4, at 107.

86 For an explanation of the US check-the-box rules, see references at supra n. 39

87 However, this is publicly known information, because it is within the law and can be consulted by everybody.

88 E.g. imagine that the report was made based on the necessities of the client to simply avoid the anticipation of distributions, and thus, recognition of income in the United States due to the application of CFC rules without any other references to tax benefits.

89 OECD, Action 2 Final Report, supra n. 4, at 108.

90 This can be seen, e.g. in the concept of 'imported mismatched'. Indeed, Action 2 refers to the possibility of 'indirectly' achieving a deduction/non-inclusion outcome using a hybrid arrangement between two other countries. The proposed rule calls for denying a deduction in the payer jurisdiction to the extent that the payee treats the payment as set off against a hybrid deduction in the payee jurisdiction. OECD, Action 2 Final Report, supra n. 4, at 83. See also the example in Figure 8 in De Boer and Marres for an illustration of the problem. De Boer \& Marres, supra n. 72, at 30.

91 Cooper explains this issue as follows: 'It has been clear for a long time that, if these recommendations [linking rules] are pursued and properly implemented, a state's tax law would become much more contingent and structurally dependent on the policies and practices of other governments'. Cooper, supra n. 38 , at 346.

92 The same could be applicable to subject-to-tax provisions and the recapture of foreign losses, which also requires a certain level of dependency on foreign laws. S. Bendlinger, Hybride Gestaltungen im internationalen Steuerrecht: der Statusbericht der OECD aus österreichischer Sicht, 22(11) Steuer und Wirtschaft International 490 (2012).

93 Lüdicke argues in this regard: 'The former [CFC rules] seems easier for taxpayers and tax administrations as it requires less technical understanding about foreign tax rules and less factual knowledge about the fact and circumstances'. Lüdicke, supra n. 43, at 313. 
because the former applies CFC rules or calculates a foreign tax credit that rely on the concept of income in the other country. However, the design of linking rules implies a more direct reference to the law of the other country, including further modifications, which indeed demonstrates a much higher degree of dependency. ${ }^{94}$

An immediate effect that might derive directly from the excessive interdependency between foreign laws provided by the OECD linking rules is the risk that the rules become 'circularly linked'. ${ }^{95}$ Indeed, if two countries decide to introduce a primary response and a defensive rule, they could result in the absurd outcome that none of the countries will know exactly when to consistently apply the antihybrid rule, as this will always be dependent on the tax treatment in the other country. For example assume a simple situation of a hybrid entity making a payment of interest to its parent company in another country. The payer country (where the hybrid entity is established) will deny a generally tax-deductible payment of interest to the extent that this is not included as ordinary income in the recipient country (primary response). Therefore, in order to decide whether to grant the deduction, the payer country must consider the tax treatment of the payer entity, but in the recipient country, because only to the extent that the payer entity is treated as a taxable entity in the recipient country, will the loan transaction be included as ordinary income of the payee entity.

On the other hand, the recipient country will include the interest payments received from the hybrid entity to the extent that a deduction was granted in the payer country (defensive rule). Therefore, once again, in order to decide whether to recognize the interest payments as ordinary income in the recipient country, this country must have certainty that a deduction was indeed granted in the payer country. As a result, both countries might ultimately face a permanent undecided position. ${ }^{96}$ As proposed elsewhere, the issue of circularity could be tackled using tie-breaker rules. $^{97}$ However, such a solution will again treat only the symptoms, avoiding a more fundamental solution that targets the divergent domestic tax characterization of entities, which is ultimately the only reason for the existence of hybrids and reverse hybrid entities. ${ }^{98}$

Finally, an excessive reliance on foreign laws might ultimately contribute to increase the transaction costs for both taxpayers and tax administrations. Taxpayers, on the one hand, in the natural attempt to escape the scope of the rules, will look for new and costly tax planning structures, being also a fruitful field for unscrupulous tax advisors. Tax administrations, on the other hand, in their need to determine whether to grant a deduction or whether to include a payment as ordinary income in the other country, will certainly require more than intuition or common sense. Indeed, a thoughtful understanding of foreign laws will be a minimum requirement the consequences of which should not be underestimated by either legislators or tax policy-makers. ${ }^{99}$

\subsubsection{Potential Economic Double Taxation Issues}

Finally, it is evident that in the OECD view of preventing (economic) double non-taxation (i.e. avoiding deduction/

\section{Notes}

94 An experience from excessive dependency on foreign laws can be taken from the modification to the German dual consolidated loss (DCL) regime. The German tax group of companies (Organgesellschaften), unlike other countries, is also applicable to dual residence entities, as it does not require that the legal seat of the members of the group to be located in Germany. Instead, it requires only that the place of management of the tax group and the controlling company (Organträger)'s participation in the tax group be allocated to a German PE (permanent establishment). This implies that, in cases where no double tax treaty is applicable, losses from dual residents of the tax group could be offset against income in Germany and in the country where the relevant legal seat is located. In order to avoid such a result, German law was modified in order to establish ded for German tax purposes to the taken also into account by a foreign country in the taxation of the controlling company, the controlled company or any other person. Nevertheless, as argued by Bärsch and Spengel, the simultaneous application of dual consolidated loss rules in Germany and other countries and the fact that the rule will apply in cases beyond dual consolidated loss cases, e.g. negative income generated by a foreign PE where the foreign income is not tax exempt in Germany due to the application of the credit method, might result in no loss set off at all. S. Bärsch \& C. Spengel, Hybrid Mismatch Arrangements: OECD Recommendations and German Practice, 67(10) Bull. Int'l Tax'n 527 (2013). Accordingly, in reference to the German experience with dual consolidated losses, Lüducke argues that collateral damage is unavoidable, and that there is no doubt in German tax literature that the provision is excessive, inappropriately drafted and not administrable. Lüdicke, supra n. 43, at 313 .

95 This issue has already been argued in literature. See e.g. K. Dziurdz, 'Circular Linked' Rules Countering Deduction and Non-Inclusion Schemes: Some Thoughts on a Tie-Breaker Test, 67(6) Bull. Int'l Tax'n (2013). See also C. Marchgraber, Tackling Deduction and Non-Inclusion Schemes: The Proposal of the European Commission, 54(4) Eur. Tax'n 141-142 (2014); Lüdicke, supra n. 43 , at 313 .

96 This can also pose the risk of determining who is getting in first. Indeed, it is an expected reaction of countries whose interests are based on the generation of revenues - which is, after all, the justification for taxation - to apply the rules according to their revenue interests. Indeed, one should consider that even though countries might sometimes act in the interest of other countries, they do so only with those partner countries with which they have a deeper affinity based on cultural, economic or geographical reasons. In all other cases, it is expected that these countries want to act in their own interests. In this regard, see Cooper, supra n. 38, at 346.

97 For a proposal of three ways of drafting those tie-breaker rules, see Dziurdz, supra n. 95, at 308-309. Nonetheless, neither the OECD nor the European Commission - as regards the hybrid mismatch arrangements rules in the ATAD I and II - provide solution on the issue of circularity of linking rules. As Marchgraber correctly argues: 'It is deplorable that the European Commission, and also the OECD, have failed to come up with suggestions on how to solve this issue [circularity of linking rules]' (parentheses added). Marchgraber, supra n. 95, at 142. For the reference to the EU ATAD I and II, supra n. 15.

98 As also recognized by Dziurdz: "The real cause of hybrid mismatch arrangements and deduction and non-inclusion schemes is the divergent domestic tax laws of countries. Unfortunately, the OECD acknowledges the harmonization of domestic laws as a way to eliminate commonly exploited differences only as a "theoretical approach" that "does not seem possible" and is noted "simply ... for the sake of completeness"'. Dziurdz, supra n. 95, at 310. In this regard also, Marchgraber argues: 'The introduction of rules countering deduction and non-inclusion schemes seems to tackle only the symptoms of a lack of harmonization of the rules'. Marchgraber, supra n. 95 , at 142.

99 As explained by Lüdicke: 'Legislators should not underestimate the theoretical and the practical difficulties which arise if the application of the domestic taxation is made dependent on the details of foreign tax laws'. Lüdicke, supra n. 43 , at 317 . 
non-inclusion schemes), linking rules might create new issues of (economic) double taxation. This could directly contradict the sound tax policy aim pursued by the BEPS Action 2 Final Report as regards hybrid entity mismatches, namely 'coherence'. ${ }^{100}$ In other words, if coherence is the pillar sustaining the concept of a hybrid entity mismatch arrangement and the application of linking rules in order to avoid double non-taxation, this should be achieved without creating new situations of double taxation.

Nevertheless, the mechanism of the OECD linking rules simply proves otherwise. For example if one assumes that denying a deduction of interest payments in the payer state to the extent that the interest is not included as ordinary income in the payee state, the logical conclusion should be that if these payments are ultimately included as ordinary income (e.g. because the other country applies different criteria for inclusion or a timing issue), the deduction should be reinstated. In other words, a denial of a deduction should not be permanent to the extent that income is recognized in the other country, unless of course the economic double taxation resulting from having a non-deduction/inclusion of income lacks importance.

The potential economic double taxation that denying a deduction might cause is indeed recognized in the design of general interest limitation rules, which generally grant a carry-forward to future years for non-deductible interest. However, this is completely disregarded in the case of the design of a primary response. ${ }^{101}$ In the same order of ideas, the circularity of linking rules might also bring new economic double taxation issues, as the undecided position of countries as regards when to apply the rules added to the intention of not losing revenues, could ultimately lead a recipient country of tax-deductible interest to tax those interest under the assumption - or perhaps simple lack of information - that an effective deduction of interest took place in the payer country. This outcome, i.e. a deduction/inclusion of income, might be supported either as a sunk cost of preventing economic double non-taxation or as a sort of 'epic tax justice' for those companies with a longstanding history of double non-taxation derived from the use of hybrid entity mismatches. However, such a conclusion is unsatisfactory from a policy perspective, especially because, once again, it deviates from the true issue surrounding hybrids entity mismatches, namely the divergent domestic tax laws of countries. ${ }^{102}$

Generally speaking, therefore, the proposed OECD linking rules demonstrate not only an unjustified preference for the avoidance of economic double non-taxation over the avoidance of economic double taxation, but also an excessive pragmatism under which taxing income somewhere - no matter where - appears to be the priority even if income is taxed twice or no base erosion actually took place. ${ }^{103}$

\subsection{Practical Concerns: The Interaction with Other Anti-Base Erosion Rules}

Besides the tax policy concerns that the OECD linking rules can give rise to, there are also more practical implications to be considered. This refers particularly to the interaction between these anti-hybrid rules and other anti-base erosion provisions, especially as regards interest limitation rules and CFC rules. The discussion here demonstrates that although the interaction between linking rules and CFC rules is well coordinated, the same conclusion cannot be drawn as regards linking rules and interest limitation rules. This might ultimately give rise to new situations of economic double taxation.

\subsection{CFC Rules and Reverse Hybrid Entities}

When analysing the application of linking rules, especially in transactions involving deductible payments received by reverse hybrid entities, it is possible to ascertain that $\mathrm{CFC}$ rules can be very effective in playing a role similar to that provided under a defensive rule. ${ }^{104}$ This idea appears to be recognized by the OECD in different passages of the BEPS Action 2 Final Report. For example the Report states:

Payments made through a reverse hybrid structure will not result in D/NI outcomes if the income is fully taxed

\section{Notes}

100 As stated by the OECD: 'The recommendations set out in this report are intended to operate as a comprehensive and coherent package of measures to neutralize mismatches that arise from the use of hybrid instruments and entities without imposing undue burdens on taxpayers and tax administrations' (emphasis added). OECD, Action 2 Final Report, supra n. 4, at 94. See also e.g. H. Ault, Some Reflections on the OECD and the Sources of International Tax Principles, 70(12) Tax Notes Int'l 1195 (2013).

101 For a further analysis of the interaction between primary response and interest limitation rules, see s. 3.3.2.

102 As Marchgraber argues: 'It might be argued that it is poetic justice that companies that have benefitted from mismatches will finally end up with a non-deduction and inclusion scheme and, therefore, the disadvantages connected with "circularly linked" rules will only compensate the previous double non-taxation. However, at least in the long term, such a situation is not satisfactory, especially because the real cause of hybrid mismatch arrangements is the divergent domestic tax laws of the countries'. Marchgraber, supra n. 95 , at 142 .

103 The BEPS Action 2 Final Report refers specifically to this issue as follows: '[ ... ] hybrid mismatch rules apply automatically and without regard for whether the arrangement has eroded the tax base of the country applying the rule. This approach assures consistency in the application of the rules (and their outcomes) between jurisdictions and also avoids the practical and conceptual difficulties in distinguishing between acceptable and unacceptable mismatches or trying to allocate taxing rights based on the extent to single taxation as an aim of international tax rules, see supra $\mathrm{n} .3$

104 See e.g. supra Fig. 8: Defensive Rule and CFC Legislation. This idea is also reinforced by the OECD BEPS Action 2 Final Report when it says: 'A payment to a reverse hybrid will not be treated as giving rise to a D/NI outcome if the mismatch is neutralized by the investor or the establishment jurisdiction adopting a specific rule designed to bring into account items of ordinary income paid to a reverse hybrid. This includes any rules [...] (including under a CFC regime) [...]'. OECD, Action 2 Final Report, supra n. 4, at 57. 
under a CFC, foreign investment fund (FIF) or a similar anti-deferral rule in the investor jurisdiction that requires the investor to include its allocated share of any payment of ordinary income made to the intermediary on a current basis. ${ }^{105}$

Similarly, the Action 2 Final Report states: 'Treating income allocated by a reverse hybrid as taxable under the laws of the investor jurisdiction would have the effect of neutralizing any hybrid mismatch under a payment to a transparent entity'. ${ }^{106}$ Accordingly, and recognizing that a proper application of CFC rules in the investors' country could resolve the hybrid mismatch, the OECD proposes that 'the payer jurisdiction could suspend the application of the hybrid mismatch rule insofar as payments were allocated to the investor in the investor jurisdiction'. ${ }^{107}$ Therefore, the Report clearly states that a defensive rule in the country where the reverse hybrid is established is unnecessary, given that CFC rules will apply in the country of the investor controlling the reverse hybrid. ${ }^{108}$

The reliance on CFC rules to counteract situations involving payments made to a reverse hybrid entity is, in principle, correct. However, it should be carefully considered, especially in light of the deficient design of CFC rules in some countries. Consider an illustration using the example of the 'same-country exception' under the US CFC rules. ${ }^{109}$ Under this domestic exception to the US CFC rules, Subpart F income (CFC income) will not include dividends, interest, rents and royalties received by a related corporation organized under the same laws as the CFC and which has a substantial part of its assets used in its trade or business located in that country. ${ }^{110}$ Therefore, if one assumes a scenario in which the United States is the country controlling the reverse hybrid that receives an interest payment from the same country from where the hybrid entity is established (i.e. State $X$ ), the same country exception would apply in order to disregard the interest received by the reverse hybrid as CFC income. In other words, no recognition of income will take place in the country of the investors (the United States in the example) due to this specific exception under the US CFC rules.

Figure 9: CFC Rules and Linking Rules

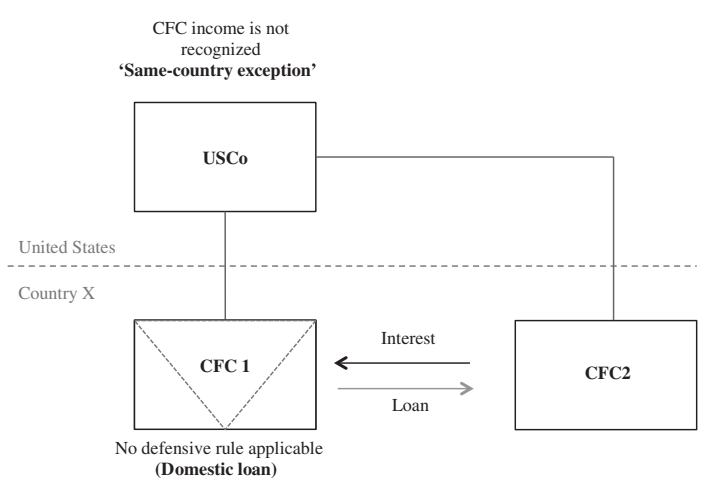

In addition, as the loan transaction between CFC1 and CFC2 is taking place in the same country (State X), the application of a defensive rule would also, in principle, be arguable. ${ }^{111}$ In other words, in spite of the fact that a deduction at the level CFC2 and a noninclusion of ordinary income at the level of CFC1 would occur in this case, this outcome would not be the result of a disparity regarding the tax transparent treatment of CFC1 in State $X$. Indeed, such a result is the outcome of a domestic tax treatment that a loan transaction will receive when the payer is a taxable entity and the payee is a partnership or a disregarded entity. In other words, the deduction/non-inclusion outcome in State $X$ will come up even if the United States were to agree on the tax treatment of CFC1 based on its treatment in State $X$. In such a case, however, the potential result will be a deduction (CFC2)/non-inclusion (CFC1)/inclusion (USCo), which should be in light of the BEPS Action 2 Final Report. However, as the disparity regarding the tax treatment of CFC1 disappears now (both the United States and State $X$ consider CFC1 as fiscally transparent), the taxation in the United States (country of the investors) will not depend on the application of linking rules. ${ }^{112}$

\section{Notes}

105 OECD, Action 2 Final Report, supra n. 4, at 64.

106 Ibid.

107 Ibid.

108 As stated by the OECD: 'A defensive rule is unnecessary given the specific recommendations in Chapter 5 for changes in CFC rules and other offshore investment regimes that would require payments to a reverse hybrid to be included in income in the investor jurisdiction'. OECD, Action 2 Final Report, supra n. 4 , at 56.

109 US: IRC s. $954(\mathrm{c})(3)$

110 US: IRC s. $954(\mathrm{c})(3)$.

111 Although the wording of the rule could include both domestic and cross-border situation, it is undeniable that hybrid entity mismatches will only occur in cross-border situations.

112 Linking rules are indeed not applicable, as no hybrid entity mismatch arrangement would exist. As to the single taxation issue, this cannot be ensured either, because it will ultimately depend on the state controlling the entity, which is not anymore a CFC. 
Figure 10: CFC Rules and Linking Rules (Ex. 2)

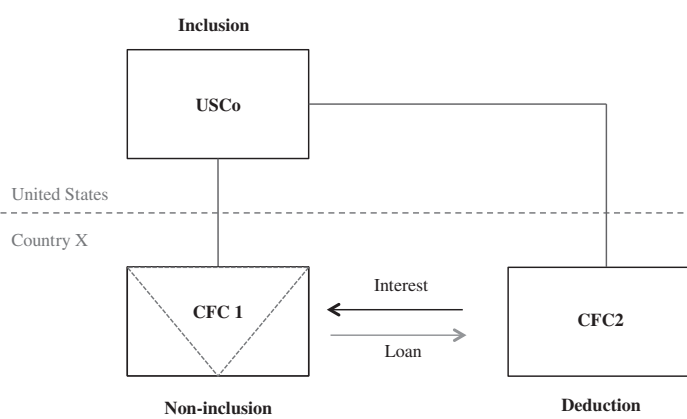

The deduction/non-inclusion outcome in the interest payment between $\mathrm{CFC} 2$ and $\mathrm{CFCl}$ is not due to the different tax characterization of $\mathrm{CFCl}$ in the United States. It is arguable thu that a defensive rule in state $\mathrm{X}$ applies.

\subsubsection{Interest Limitation Rules and Hybrid Entities}

Generally speaking, interest limitation rules provide for a limitation on the deductibility of net interest expense, which limitation is normally calculated as a percentage of taxable EBITDA. ${ }^{113}$ The application of interest limitation rules thus implies that a certain amount of business interest expense (which is normally deductible as an ordinary expense in a taxable year) will be no longer deductible under certain circumstances. ${ }^{114}$ As such, it is predictable that interest limitation rules could have implications regarding the application of both a primary response and a defensive rule, especially as regards payments made by hybrid entities.

As to the primary response, the author has already stressed that the purpose of this rule is to deny a deduction to the extent that the corresponding payment is not included as ordinary income in the payee country. ${ }^{115}$ Now, if one considers that countries can also provide for a general interest limitation under their domestic laws, the question concerns what to do when these two provisions concur together. The BEPS Action 2 Final Report refers to this issue giving priority to the anti-hybrid rules using arguments connected with the functions of the rules and logic. ${ }^{116}$ According to the OECD, while linking rules would provide for adjustments regarding particular items that are taken into account for the purposes of calculating a taxpayer's overall income or expenses, interest limitation rules would apply in a more general manner. Thus, the application of a primary response should precede the application of interest limitation rules as a matter of logic. ${ }^{117}$ This position is nevertheless arguable, especially considering that the economic effect of both interest limitation rules and a primary response is exactly the same, namely that they both deny a deduction at the level of the payer, subsequently increasing the taxable base of the taxpayer in the payer country.

This can be illustrated as follows. Assume that a corporate taxpayer has gross revenue of 200 and interest expense of 100 , and its taxable income is $100 .{ }^{118}$ Now, if a general interest limitation rule were to apply so as to limit its deduction of 100 of interest, ${ }^{119}$ the economic result would be that the payer's taxable base for that calendar year would be increased by the same amount of non-deductible interest (100). In other words, the amount of non-deductible interest will be added back to the taxable base of the payer, thereby increasing its overall tax burden. Similarly, if one assumes now that the loan transaction involves the same payment of interest (100) but this is made from a hybrid entity, the same amount of interest payments would be denied, and therefore, added back to the taxable income of the payer according to the

\section{Notes}

113 Interest limitation rules can also be designed as a fixed debt-equity ratio, which is known as 'thin capitalization rules'. However, many countries opt today for a limitation on the deduction of net interest expenses up to $30 \%$ of the amount of EBITDA to the extent that the net interest expenses do not exceed a certain threshold, in some cases, and, in other cases, only if the entity in excess of indebtedness is part of a tax group. K. von Brocke \& E. Garcia Perez, Group Financing: From Thin Capitalization to Interest Deduction Limitation Rules, 16(1) Int'l Transfer Pricing J. 31 (2009). E.g. in Germany, as a general rule, a 'business' (Betrieb) is limited to deducting net interest expenses, i.e. the amount after offsetting the interest expenses against the interest earnings of the business as business expenses up to $30 \%$ of the amount of the taxable EBITDA. If there is thus an excess of net interest expenses, this is not deductible in the fiscal year, although it can be carried forward indefinitely and deducted in the subsequet fiscal years subject to the same threehold limitation. This general the , however, has some exceptions. ristly, it only applies to the extent

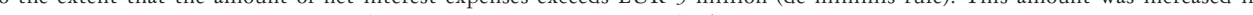
original amount was EUR 1 million. See DE: Citizen Relief Act [Birgerentlastungsgesetz] of 16 July 2009, BGBl 1, 1959 (2009) and Growth Acceleration Act [Wachstumsbeschleunigungsgesetz] of 22 Dec. 2009, BGBl 1, 3950 (2009). See also in reference to the German rule, e.g. M. Scheunemann \& T. Müller-Duttiné, New German Tax Rules on Financing Expenses, 35(8/9) Intertax 518 (2007); A. Fross, Earnings Stripping and Thin Cap Rules: Maintaining an Arm's Length Distance, 53(10) Eur. Tax'n (2013). A mirror rule has also been introduced as secondary EU law. EU ATAD I, supra n. 15, Art. 4. Similarly, the OECD recommends interest limitation rules in BEPS Action 4 Final Report. OECD, Limiting Base Erosion Involving Interest Deductions and Other Financial Payments - Action 4: 2015 Final Report, OECD/G20 Base Erosion and Profit Shifting Project (OECD Publishing 5 Oct. 2015). See also OECD, Limiting Base Erosion Involving Interest Deductions and Other Financial Payments, Action 4 - 2016 Update: Inclusive Framework on BEPS, OECD/G20 Base Erosion and Profit Shifting Project (OECD Publishing 22 Dec. 2016).

114 The amount of non-deductible expenses can nonetheless be carried forward. Yet, even though an unlimited carry-forward is offered under the laws of certain countries, its practical application is sometimes limited. E $g$. in Germany this happens in case of the discontinuance of the business or change of control. DE. S. 4(h)(5)(1) Income Tax Act [Einkommensteuergesetz, EStG]. See also C. Knöller, The Efficacy of Thin Capitalization Rules and Their Barriers: An Analysis from the UK and German Perspective, 39(6/7) Intertax 317, 324-325 (2011).

115 See supra s. 3.1.

116 OECD, Action 2 Final Report, supra n. 4, at 97.

117 As stated by the OECD: '[t $t$ he hybrid mismatch rule makes adjustments in respect of particular items that are taken into account for the purposes of calculating taxpayer's overall income or expenses and therefore, as a matter of logic, would generally apply before any such general or overall limitation'. Id. Similarly, the OECD states: 'Rules to address hybrid mismatch arrangements should be applied by an entity before the fixed ratio rule and group ratio rule to determine an entity's total net interest expense. Once this total net interest expense figure has been determined, the fixed ratio rule and group ratio rule should be applied to establish whether the full amount may be deducted, or to what extent net interest expenses should be disallowed'. OECD, Action 2 Final Report, supra n. 4, at 103.

118 This example assumes that no other income is received that year, including no interest income

119 Assume that the amount of 100 corresponds to $30 \%$ of its EBITDA 
primary response. Therefore, economically speaking, it would make no difference - in principle - if one applies a primary response or an interest limitation rule first.

However, still practical reasons allow the author to disagree with the OECD position and to argue that interest limitation rules should indeed be applied before hybrid entity mismatch rules. First, while interest limitation rules generally offer the possibility to carry forward the non-deductible interest, linking rules do not grant this option. This could make the potential outcome of economic double taxation a permanent burden for the payer. Consider an illustration of this by means of an example involving two scenarios. In the first scenario, a corporate taxpayer in State $Y$ is paying 200 of interest to its parent company in State $X$. The taxpayer in State $X$ is regarded as a tax transparent entity by State $X$, while as a tax opaque or taxable entity in State $Y$. Also assume that State $Y$ has an interest limitation rule that provides for a limitation on the deductibility of interest up to $30 \%$ of EBITDA, which is now assumed to be 400. In this scenario, a primary response is applied before interest limitation rules.

Figure 11: Primary Response and Interest Limitation Rules (First Scenario)

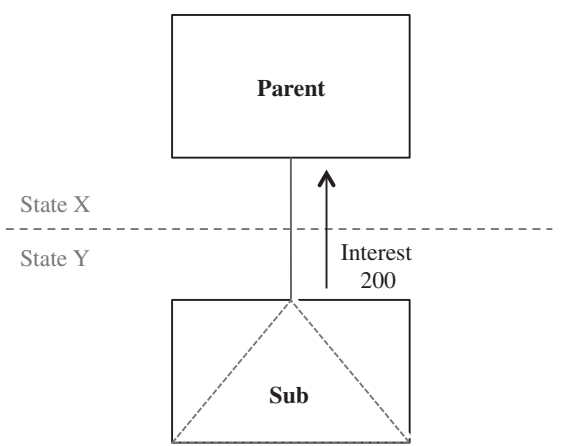

As the primary response applies first, the full amount of 200 interes deduction will be denied. Accordingly, neither a carry-forward of the non-deductible expenses nor a possibility to get back the deduction in the next years will be allowed if the interest are finally included as ordinary income in State $\mathrm{X}$
As noted, therefore, applying the primary response first means that a deduction of interest expense (200) is applied at the level of the payer, because the loan and the respective amount of interest are disregarded in the country of the payee, and thus, not included as ordinary income in State $X$. Likewise, this nondeductible interest will not be carried forward to future years. Accordingly, a potential interest limitation rule will not be applicable either, as there is no remaining interest upon which to apply this provision. Indeed, if applied, it would mean that a double non-deduction is affecting the same item of expense, which is an issue that should certainly be avoided. ${ }^{120}$ Therefore, although pragmatically effective, ${ }^{121}$ the application of a primary response before interest limitation rules has the risk of creating a potential - permanent - economic double taxation if the interest payments are ultimately included as ordinary income in State $X$, raising also important issues as regards the ability-to-pay principle. ${ }^{122}$

In the second scenario, assume the same facts as above with the only difference that the interest limitation rule applies before the primary response. ${ }^{123}$

Figure 12: Primary response and interest limitation rules (second scenario)

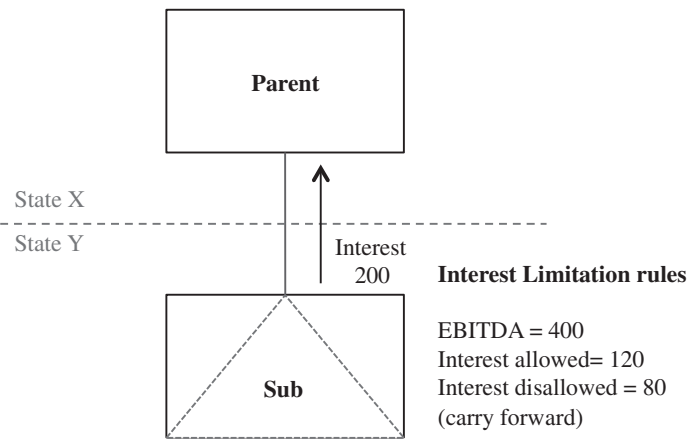

As the interest limitation rule applies first, only 80 interest deduction will be disallowed under this rule. However, this amount can be carried-forward avoiding thereby a potential economic double taxation in the case the interest are finally included as ordinary income in State X. The amount of 120 can still be disallowed under the application of a primary response. However, this amount is lower than the original 200 in the first scenario.

\section{Notes}

120 The OECD is indeed concerned about denying a deduction twice when it provides: "The mechanism for coordinating the interaction between the two rules [interest limitation and hybrid mismatch rule] will depend on how the interest limitation rule operates; however, the interaction between these rules should not have the net effect of denying a deduction twice for the same item of expenditure'. OECD, Action 2 Final Report, supra n. 4, at 98.

121 In this example, the full amount of interest paid will be disallowed, which in the perspective of the primary response would solve the hybrid mismatch arrangement.

122 Although the analysis of this specific issue exceeds the purpose of this article, it is important to stress that the ability-to-pay - when applied to corporations - generally means that these corporations should be able to use all the ordinary expenses generated during a calendar year in order to set off the income of that year. As such, when an interest limitation rule or a primary response denies a proportional amount of these deductible expenses, the ability-to-pay of that taxpayer might be at risk. This has been a particularly sensitive issue in Germany where the compatibility of the 'German interest barrier' [Zinsschrancke] and the 'objective net principle' [objektives Nettoprinzip] - a Constitutionally recognized principle that extends the application of the ability-to-pay principle to corporations - has been largely discussed. Indeed, this important debate has even been considered in a recent decision of the Federal Tax Court [Bundesfinanzhof], which confirmed most of the constitutional concerns as regards the German interest barrier. Yet, the domestic debate remains open, at least until a formal decision from the German Constitutional Court [Bundesverfassungsgericht] comes up. For the decision of the German Federal Tax Court, see DE: BFH, 14 Oct. 2015, I R 20/15. Recently on this topic, see also e.g. S. Lampert, T. Meickmann \& M. Reinert, Art. 4 of the EU Anti Tax Avoidance Directive in Light of the Questionable Constitutionality of the German 'Interest Barrier' Rule, 56(8) Eur. Tax'n (2016). For a brief analysis of this issue but in reference to the new Italian Interest Limitation rule - which nonetheless resembles the German rule, see G. Vanz, The Italian Interest Limitation Rule: Constitutional Issues, 58(4) Eur. Tax'n (2018). The German Constitutional analysis of interest limitation rules is also particularly relevant at the level of the EU, because the EU ATAD I specifically includes an interest limitation rule inspired in the German domestic interest barrier. This certainly possesses even more interest as regards the conclusions achieved by the German Constitutional Court. For a reference to the text of the EU ATAD I, see EU ATAD I, supra n. 15, Art. 4 (interest limitation).

123 The example assumes an interest limitation of $30 \%$ of the amount of EBITDA. 
In this case, the allowable deductible interest expenses would amount to 120 , ensuring thus that the primary response - which fulfils the same economic role as interest limitation rules - is applied only to this amount of effectively deductible interest. In other words, applying interest limitation rules before a primary response helps to better determine the amount of deductible and non-deductible payments for the payer company, ensuring also that the remaining amount of interest disallowed under the application of interest limitation rules (80) may be carried forward to further years avoiding - at least as regards this amount - a permanent economic double taxation effect. ${ }^{124}$ This outcome appears, in principle, to be more proportionate than disallowing the full amount of interest payments (200) - first scenario - without the possibility to carryforward or to reuse the interest deductions in future years if the parent company includes that amount of interest as ordinary income in State $X$. Therefore, the combined application of interest limitation rules - first - and primary response - second - may not only resolve the hybrid mismatch arrangement, but also could generate fairer results for the whole group.

Finally, and considering also the linking effect of a primary response and a defensive rule, one could conclude that the application of an interest limitation rule before a primary response would also impact the application of a defensive rule. Indeed, as the defensive rule applies only to the amount of interest 'effectively deducted' in the payer's state, the fact that an interest limitation rule is applied before a primary response would also make a difference in determining the amount to which a defensive rule might potentially apply, taking into consideration of course that a defensive rule will apply only to the extent that the payer state did not apply a primary response first, i.e. to the extent the payer country granted a deduction on a taxdeductible payment made by a hybrid entity. Consider an illustration of this using the same scenarios described above. In the first scenario, if a deduction of 200 is ultimately granted in full at the level of the payer, the defensive rule will apply on that full amount. However, if the interest limitation rule were to be applied first, the 'effectively deducted' expenses would be immediately reduced to 120 . Thus, a defensive rule in the payee State $X$ will be necessarily limited to 120 (rather than being applied on the full 200). This result appears also to be more consistent with the coherence aimed at by the BEPS Action 2 Final Report. ${ }^{125}$

\subsection{Recommendation 5.2 of the BEPS Action 2 Final Report: A Step in the Right Direction}

An interesting deviation as regards cases involving a payment made to a reverse hybrid entity can be found in the Recommendation 5.2 of the BEPS Action 2 Final Report. ${ }^{126}$ According to this recommendation, the tax transparency treatment of an entity in its country of establishment should be restricted, such that the tax transparent entity should be rather treated as a taxable entity in the country of establishment to the extent that this entity derives foreign-source income that is not otherwise subject to taxation in its country of establishment and such income is allocated under the domestic laws of that country to a non-resident investor that is in the same control group as the entity. ${ }^{127}$ Therefore, taking the example of Figure 4: Illustration Using a Reverse Hybrid Entity Structure, the tax transparency treatment in the country where the reverse hybrid entity is established (State $B$ ) should be replaced by treating the entity as a taxable entity. This would ensure that the interest payments received are included as ordinary income in State $B$, which comes closer to a coordination rule. ${ }^{128}$

\section{Notes}

124 One could also argue that the carry forward accomplishes a more fundamental role, which is to be in line with the ability-to-pay principle. See supra $\mathrm{n}$. 122

125 OECD, Action 2 Final Report, supra n. 4, at 94 . See also the analysis at supra s. 3.2.3.

126 OECD, Action 2 Final Report, supra n. 4, at 64-65.

127 Ibid.

128 As stressed already in this article, this idea of coordination has already been implemented in countries such as Denmark. DK: s. 2C of the Corporate Income Tax Law (SELSelskabsskatteloven). The Danish rule - as regards reverse hybrid entity transactions - provides that certain entities normally treated as fiscally transparent in Denmark, e.g. limited partnerships (kommanditselskaber), partnerships limited by shares (partnerselskaber) and branches of non-Danish entities, must be recharacterized as taxable entities if: (1) the direct owners/partners holding more than 50\% of the capital or voting rights are tax residents in one or more foreign jurisdictions, the Faroe Islands or Greenland, and (2) the jurisdiction where the owners are tax resident either considers the Danish entity to be a separate taxable entity, or it does not exchange information with the Danish tax authorities. For a further analysis, see Møllin Ottosen and Nørremark, supra n. 13; Bundgaard, supra n. 13; J. Wittendorff, supra n. 13; Dell'Anese, supra n. 3; Parada, supra n. 6, at 168-172. Similarly, the EU ATAD II proposed a rule resembling the Danish rule. Generally speaking, the rule provides for a recharacterization of the tax transparent payee entity established in the EU to the extent the majority of its owners are located in a non-EU Member State that considers the same entity to be a taxable entity. Art. 9a EU ATAD II reads as follows: 'Where one or more associated non-resident entities holding in aggregate a direct or indirect interest in $50 \%$ or more of the voting rights, capital interests or rights to a share of profit in a hybrid entity that is incorporated or established in a Member State, are located in a jurisdiction or jurisdictions that regard the hybrid entity as a taxable person, the hybrid entity shall be regarded as a resident of that Member State and taxed on its income to the extent that this income is not otherwise taxed under the laws of the Member State or any other jurisdiction'. EU ATAD II, supra n. 15, Art. 9a. The rule is thus intended to ensure that income does not remain untaxed in the EU while not being taxed anywhere else either. T. Balco, 2. Anti-Avoidunce Dirctive, 57(4) Eur. Tax'n 132 (2017). For a further a lis 401, 404 (2017). For an analysis as regards these coordination experiences (i.e. Denmark and the EU ATAD II) and the application of the new Art. 1(2) OECD Model Tax Convention/ Art. 3(1) MLI, see Parada, Hybrid Entities and Conflicts of Allocation of Income Witbin Tax Treaties, supra n. 15. 
Figure 13: Recommendation 5.2. (BEPS Action 2 Final Report)

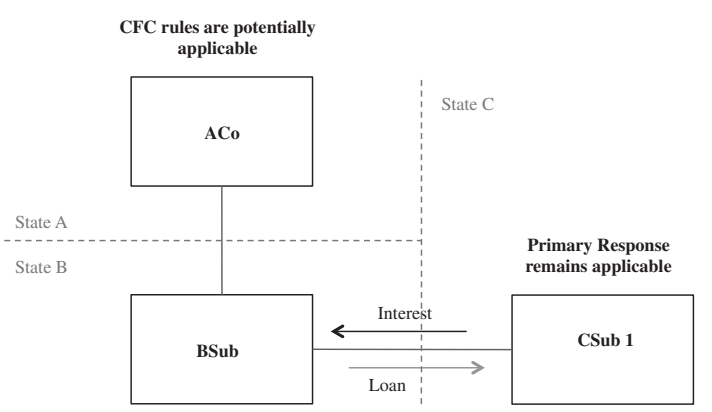

The tax transparency treatment of BSub in State B is replaced by treating BSub as a taxable entity. Interest are thus included as ordinary income.

However, this does not prevent the application of CFC rules by State $A$, which might still give rise to double taxation issues. ${ }^{129}$ Similarly, in the assumption that State $C$ also includes a primary response and a defensive rule, nothing would prevent State $C$ from denying a deduction of interest before the application of Recommendation 5.2. Therefore, if the interest payments were included as ordinary income in State $B$ by the recharacterization of BSub as a taxable entity, an issue of economic double taxation could still arise. This could evidently be avoided with the complete absence of linking rules. In other words, a rule providing for a recharacterization of the reverse hybrid entity at residence could by its own deal more efficiently with hybrid entity mismatch arrangements without needing rules linking deductions in one country with the respective inclusion of income in the other.
There are still other concerns that Recommendation 5.2 might generate and which are related to issues of legal certainty and non-discrimination. As to legal certainty, non-residents owners might indeed feel affected by a rule providing for a recharacterization of a tax transparent entity as a taxable one. Indeed, it is undeniable that tax transparency is an effective way to attract foreign investors and to ensure tax neutrality among them. Therefore, taxpayers might rightfully be concerned by the fact that electing to do businesses in a given country through, for example, a partnership (among other reasons, because of the tax transparent treatment of this entity) does not guarantee that in future such tax treatment will be respected, which might ultimately reduce the attractiveness of the investment. ${ }^{130}$

As to non-discrimination, it is also evident that implementing a rule which provides for a recharacterization of a tax transparent entity as a taxable one only in relation to non-resident investors might be considered discriminatory. This is especially critical in the context of the European Union and fundamental freedoms. ${ }^{131}$ However, an immediate way to avoid discrimination issues would be to apply the limitation on tax transparency equally to both residents and non-residents partners or to apply this only to the extent that the majority of the investors are resident in a country where the entity is treated as tax opaque. $^{132}$

Yet, this would not eliminate the concerns mentioned above. For example if Recommendation 5.2 were to be applicable without distinguishing between resident and non-resident taxpayers, the practical impact would be zero, as hybrid entity mismatches can arise only in cross-border situations. In other words, Recommendation 5.2 could still imply a hidden - or

\section{Notes}

129 This problem is recognized in the BEPS Action 2 Final Report: 'By treating the entity as a resident taxpayer, this will eliminate the need to apply the reverse hybrid rule to such entities and the investor jurisdiction could continue to include such payments in income under Recommendation 5.1 but provide a credit for any taxes paid in the establishment jurisdiction on the income that is brought into account under such rules'. OECD, Action 2 Final Report, supra n. 4, at 65.

130 The tax transparency treatment is indeed an important feature of tax systems, because they provide simplicity and neutrality among investors. E.g. the taxation of partnerships or pass-through entities has certainly encouraged its use in the United States, especially in relation to the avoidance of economic double taxation. This is because profits from a Corporation are generally subject to double taxation in the United States. First, a corporate income tax is applied at the level of the corporation. Second, personal income tax is applied at the level of the shareholders on the distribution of profits, who are also not entitled to a tax credit for the corporate income already affecting the profits at the level of the entity. McDaniel et al. explains it as follows: 'Since the partnership is treated as a conduit for tax purposes, profits are taxed only once, in contrast to the taxation of corporate profits, first when earned by the corporation, and again, when distributed to shareholders'. McDaniel, McMahon \& Simmons, supra n. 8 , at 1. Similarly, he use of losses makes a difference when electing between forming a Corporation or a Partnership. As McDaniel et al. state: 'In addition, when the enterprise realizes losses, the partners may deduct the losses currently on their own tax returns, while losses at the corporate level may not be deducted by shareholders'. McDaniel, McMahon \& Simmons, supra n. 8, at 1 .

131 In order to determine whether a national rule creates or not tax discrimination, the Court of Justice of the European Union (ECJ) conducts an analysis involving different phases. In the first place, the ECJ determines which of the fundamental freedoms is indeed potentially infringed. Once this has been done, it proceeds to make comparability analysis, by which it compares the situation of the complaining taxpayer - normally, a non-resident with economic connection with the host country - with a comparable domestic situation in order to determine whether or not these two comparable situations are treated equally. If the result of this second phase is that the national rule is discriminatory, there must be still justifications for the discrimination. Yet, even existing a justification ground, the rule needs to be considered proportional. R. Mason \& M. Knoll, What Is Discrimination?, 121(5) Yale L.J. 1014 (2012). For a deeper analysis of the principle of non-discrimination in EU Law, see N. Bammens, The Principle of Non-Discrimination in International and European Tax Law, IBFD Doctoral Series, vol. 24 (IBFD 2012). For a specific analysis of compatibility between linking rules and EU Law, see e.g. J. Di Maria, Comparability in the case of Hybrid Mismatch: In Search of an Approach Suitable for the Current European Landscape, in Non-Discrimination in European and Tax Treaty Law (K. Dziurdz and C. Marchgraber eds, Linde 2015). See also J. Bundgaard, Hybrid Financial Instruments and Primary EU Law-Part 1, 53(11) Eur. Tax'n (2013); J. Bundgaard, Hybrid Financial Instruments and Primary EU Law-Part 2, 53(12) Eur. Tax'n (2013); S. Kudert \& C. Kahlenberg, Extension of the Domestic Correspondence Principle, 54(1) Eur. Tax'n (2014); O. Thömmes \& A. Linn, The New German DCL and Dividends Matching Rules and EU Law, 42(1) Intertax (2014); J. Becker \& T. Loose, Zur geplanten Ausdehnung des materiellen Korrespondenzprinzips auf hybride Finanzierungen, 21(19) Internationales Steuerrecht (2012); O. Dörfler, R. Heurung \& G. Adrian, Korrespondenzprinzip bei verdeckter Gewinnausscbïttung und verdeckter Einlage, 45(12) Deutsches Steuerrecht 514 (2007); Parada, supra n. 6, at 325-343; Rust, supra n. 60; Marchgraber, supra n. 95.

132 A design of these types of rules attending to the percentage of ownership - voting rights or capital - held by non-residents investors can be seen in the Danish anti-reverse hybrid entities rules and Art. 9a EU ATAD II. For a further reference on these rules, see supra n. 15 and supra n. 128 
tacit - discrimination ${ }^{133}$ Similarly, if Recommendation 5.2 were to be applicable only to the extent that the majority of the investors were resident in a country where the entity is treated as tax opaque, the application of the rule might be regarded as disproportionate, raising questions regarding the protection of minority shareholder rights. ${ }^{134}$ Moreover, in the worst-case scenario, such a recommendation could ultimately affect the decisions of domestic investors to carry out businesses based on the residence of foreign investors and the tax treatment of the entity in their country. Such a result would not only be absurd, but also could give rise to significant limitations on the economic development of the country where the entity is established in the long-term.

In spite of all the downsides of Recommendation 5.2, and perhaps also the consequentialist approach still present within the proposal, it is important to highlight that such a rule represents a little step in the right direction to achieving a more fundamental solution to hybrid entity mismatches. Indeed, as provided elsewhere, rules targeting the disparate tax characterization of entities either through coordination ${ }^{135}$ or even mutual recognition, ${ }^{136}$ seem to better accomplish the role of eliminating the hybrid entity mismatch - the true reason of hybrids and reverse hybrid entities, while also avoiding tax outcomes that could be seen as undesirable. ${ }^{137}$

\section{Conclusion}

Since the release of the BEPS Action 2 Final Report, one can see how the consequentialist approach of matching tax outcomes has slowly gained ground, introducing into the international tax debate both the elusive notion of hybrid entity mismatch arrangements and the complex set of rules proposed to counteract them. This idea, which finds its foundation in the assumption that income should be taxed somewhere - no matter where, not only deviates from the core of the problem regarding hybrids and reverse hybrid entities (i.e. the different characterization of the same entity by two or more states), but also has been able to convince the vast majority of tax scholars and tax policymakers that this is indeed the only possible path to be followed.

In contrast, this article has demonstrated that both the diagnosis of the problems and the remedies proposed to counteract them are indeed very questionable, from both a tax policy perspective and a practical perspective. From a tax policy perspective, it is undeniable that the pragmatic construction of the notion of a hybrid entity mismatch arrangements is debatable, especially when other elements such as group taxation and multi-year patterns are introduced into the scene. Indeed, in most of those cases, double non-taxation (the core of the notion of hybrid entity mismatch arrangements) will always become more apparent than real. Accordingly, the design of rules created to counteract these situations (linking rules) is not exempt from criticism either. As stressed in this article, the idea of denying a deduction in the payer state if a payment is not recognized as income in the payee state, or recognizing a hybrid entity transaction originally disregarded in the payee state due to the tax transparency treatment given to the payer entity, is indeed more complex than how it is presented in the BEPS Action 2 Final Report. This can be seen, for example, in the circular effect that linking rules could give rise to when applied uniformly and without exceptions all around the world. Similarly, the limitation on the scope of the rules to 'structured arrangements' and 'control groups' has not contributed to simplify the application of a primary response or a defensive rule either. On the contrary, and especially referring to the concept of 'structured arrangements', this has created more uncertainty and appears to be the perfect source for future interpretation conflicts, as

\section{Notes}

133 In a similar conclusion regarding the OECD linking rules in the context of EU fundamental freedoms, see Rust, supra n. 60, at 313 and 320.

134 These concerns have also been stressed as regards the anti-reverse hybrid entity rules in Denmark and also as regards Art. 9a EU ATAD II. Parada, supra n. 6, at 171-172 \& 183.

135 This author has recently proposed a rule denominated 'reactive coordination rule', which aims to be a domestic alternative to linking rules. The rule proposed to align the characterization of entities according to the tax characterization of the entity given in its home country, i.e. the country where the entity is formally and legally organized. Accordingly, the proposal is based on three main tax policy ideas that support its whole design: simplicity, coherence and ease of administration and it is also completely agnostic as regards to the double non-taxation outcome. For a full analysis of this proposal, see Parada, supra n. 6, at 353-398. For an in-depth analysis of this proposal within the tax treaty context, see Parada, Hybrid Entities and Conflicts of Allocation of Income Within Tax Treaties, supra n. 15.

136 In the context of the European Union, Fibbe proposes a uniform classification method within the EU by mutually recognizing the tax classification in the host country. This mutual classification method is based in the principle of mutual recognition of entities and it would be materialized in a EU Directive. For further details on Fibbe's proposal, see G. Fibbe, EC Law Aspects of Hybrid Entities, Doctoral Series, vol. 15, 293-384 (IBFD 2009). See also DE: ECJ, 6 Dec. 2007, Case C-298/05, Columbus Container Services B.V.B.A. \& C o. v. Finanzamt Bielefeld-Innenstadt, ECLI:EU:C:2007:754, where the ECJ argued that a disparity derived from the autonomous classification of entities within EU Member States was an issue beyond the fundamental rights and freedoms. Fibbe, based in the outcome in Columbus Container Services, reinforces the idea of introducing a Directive on Mutual Recognition of Entities within the EU. As stated by Fibbe: 'If the ECJ did not consider in the Columbus case that the consequence of a classification conflict is a forbidden restriction [...] Therefore, the new directive introduces a better system than the current tax classification methods that are applied autonomously [...]'. Id., at 378. In spite of the fact that this author agrees that the EU is a better place for achieving harmonized or coordinated results, harmonization in the characterization of entities would still be a utopian idea to implement in a global scale. Likewise, if implemented only within the EU, it would still leave open issues of EU, it would still leave op issues of haracterization of entities rather than harmonization (or mutual recognition). For Parada's global alternative ('reactive coordination rule'), see Parada, Hybrid Entities and Conflicts of Allocation of Income Within Tax Treaties, supra n. 15

137 In a more radical proposal, Rosembuj argues for taxing pass-through entities as corporations. However, in this author's view, Rosembuj does not provide solid arguments in order to support his approach beyond of advocating for a sort of neutrality in the tax treatment of entities engaged in similar businesses. For the proposal, see T. Rosembuj, Hybrid Entities: Why Not Tax Pass-Througbs as Corporations?, 40(5) Intertax 298 (2012). 
this concept seems to be a box into which everything could fit in. In this vein also, the design of linking rules has shown to be extremely dependent upon foreign laws, and curiously also, appears to give priority to the avoidance of economic double non-taxation, even at the cost of creating new situations of economic double taxation.

From a practical perspective, the author concludes that the application of linking rules still raises concerns in relation to its interaction with other anti-base erosion provisions, such as interest limitation rules and CFC rules. Regarding CFC rules, the author agrees that the priority given to the application of CFC rules over linking rules in cases involving reverse hybrid entities receiving deductible payments appears to be logical. In contrast, however, the author disagrees with the use of interest limitation rules after the application of a primary response. As demonstrated here, even though both rules generate similar economic outcomes (denial of a deduction and an increase in taxable income in the payer state), interest limitation rules should have priority of application, as they generally avoid potential economic double taxation through the carry-forward of non-deductible amounts. If this hierarchy of application were ultimately followed, the hybrid entity mismatch would be resolved without needing to resort to the complex linking rules, thereby also avoiding potential economic double taxation issues.
As a result, in the author's opinion, the current international scenario stresses the need for a change in the way the use - and misuse - of hybrid entity mismatches is understood. This change should start with the adoption of a less consequentialist approach as regards both the diagnosis of the problems and the design of rules created to counteract them. In other words, this new approach should start from the basis of disregarding double non-taxation as the central element of the concept of hybrid entity mismatches and as the core of the design of anti-hybrid rules, redirecting attention to the only issue that really matters as regards hybrid entity mismatches, namely the disparate tax characterization of the same entity by two or more states. Such an approach could ultimately open the door for more fundamental and coordinated solutions, including rules aligning the tax characterization of entities. ${ }^{138}$ To assume the challenge of analysing specific proposals here appears nonetheless to be inadequate and excessive considering the limited scope of this article. Nevertheless, this should not prevent the author from emphasizing the urgent need for action, especially before all countries become convinced regarding the diagnosis of the sickness and that matching tax outcomes is indeed the only - or at least the most preferable - possible cure.

\section{Notes}

138 Examples of coordination have already been provided in this article. See e.g. supra n. 15, supra n. 135 and supra n. 136. 